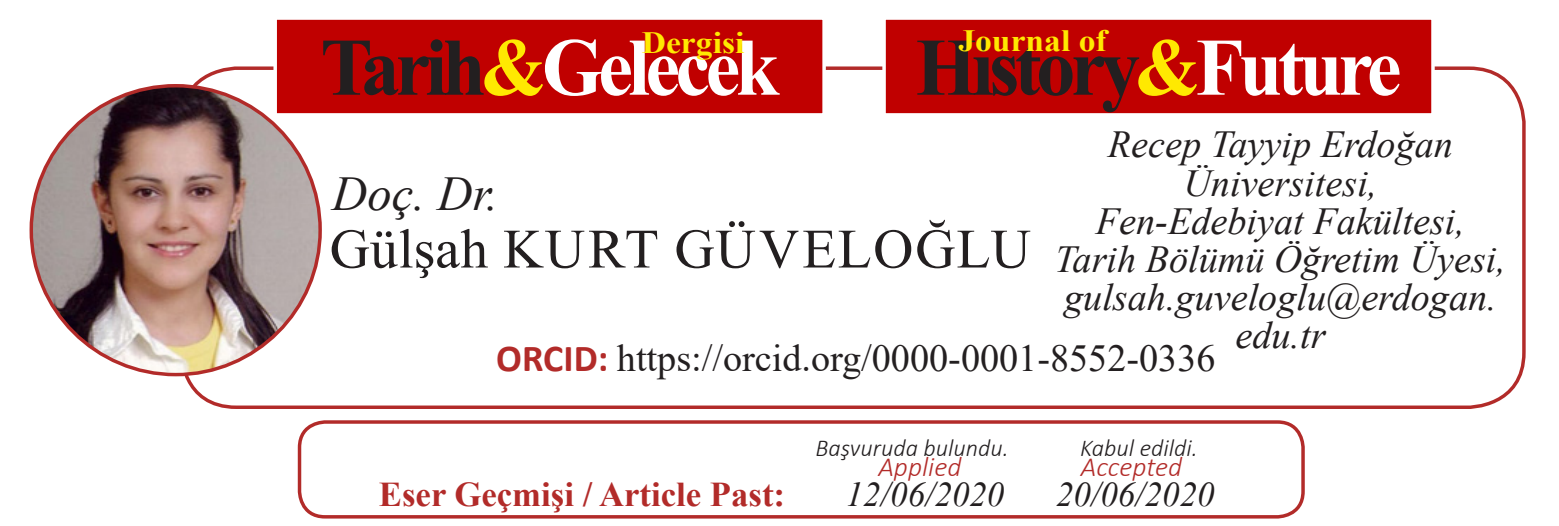

Araștırma Makalesi

DOI: http://dx.doi.org/10.21551/jhf.751954

Research Paper

Orjinal Makale / Orginal Paper

\title{
Türkiye Cumhuriyeti Devlet Salnamelerinde Rize (1925-1929)
}

\author{
The City of Rize According to State Yearbooks of Turkish Republic
}

(1925-1929)

\section{$\ddot{O} z$}

Osmanlı Devletindeki salname geleneğinin Türkiye Cumhuriyetindeki uzantısı sayllabilecek devlet salnameleri merkez ile taşra arasında iletişimi sağlayan birer araç olarak önemli bilgiler ihtiva ederler. Vilayet Salnameleri de devlet salnameleri gibi illerin idari, demografik ve sosyo-iktisadi durumlartna dair bilgileri sunarlar. Bu eserlerde tek tek illere ait bilgilerin yanısıra devletin idare mekanizması ve bölgelere atanan idareciler ve mülki teşkilat da yer alır. Sal:yll ve name:mektup, kitap kelimelerinden oluşan salname kelimesi yıllık, nevsal anlamına gelmektedir. 1847-1912 arasında düzenli olarak yayınlanan devlet salnameleri savaş yıllarında çıkarılamamış, 1918'de sonuncusu yayınlanmış; Cumhuriyet döneminde 1925 'ten itibaren tekrar yaylnlanmaya devam etmiş; 1928 yllindan itibaren Latin harfleriyle çıkarılan devlet salnameleri yayınlanmıştır. Bu salnamelerde her ile ve kazaya ait coğrafi, tarihi bilgilerin yanısrıa illerin sosyal ve ekonomikyapısı hakkında detaylı ve istatistiki verilerin bulunması önemlerini artırmaktadır. Bu çalışmada 1925 ten 1929'a kadar çıkarılan dört Türkiye Cumhuriyeti Devlet salnamesinden faydalanılmıştır. 1925-26 salnamesi 884, 1926-27 salnamesi 1127, 1927-28 salnamesi 1300, 1928-29 salnamesi ise 759 sayfadan oluşmaktadir. Bahsedilen salnamelerde yer alan bilgiler ışı̆̆ında Cumhuriyetin ilkyıllarını kapsayan bu dönemde Rize ilinin durumu aydınlatılmaya çalışılacaktır.

Anahtar Kelimeler: Salname, Türkiye Cumhuriyeti Devlet salnamesi, Rize. 


\section{Abstract}

State yearbooks as an extension of "salname" tradition in Ottoman Empire to Republic of Turkey, contain important information as a tool for communication between the center and the provinces. The provincial yearbooks also provide information on the administrative, demographic and socio-economic status of the provinces, such as the state yearbooks. In addition to the information of the individual provinces, these works include the administrative mechanism of the state and the administrators assigned to the regions and the civil service. The word salname, which consists of the words sal: year and name: letter, book, means annual. State yearbooks, which were published regularly between 18471912, could not be issued in the war years, the last one was published in 1918; It continued to be republished in the Republican era from 1925; State yearbooks, issued in Latin letters since 1928, were published. This study has been benefited four state yearbook issued in 1925 until 1929. The 1925-26 yearbook consists of 884, the 1926-27 yearbook is 1127, the 1927-28 yearbook is 1300, and the 1928-29 yearbook consists of 759 pages. In the light of the information in the aforementioned yearbooks, in this period covering the first years of the Republic, the situation of Rize province will be tried to be clarified.

Keywords: Yearbook, State yearbook of Turkish Republic, Rize.

\section{Giriș}

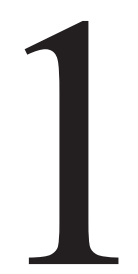

461 y1lında Osmanlı hakimiyetine giren Rize, 1878'e kadar Trabzon merkez sancağına bağlı bir kaza idi. 1878 sonrasında Rize, sancak merkezi olmuş ve Lazistan olarak anılmaya başlamıştır. ${ }^{1}$ Kura-yı Seba (İkizdere), Karadere (Kalkandere) ve Mapavri (Çayeli) kazalarına Hopa ve Atina (Pazar) kazalarının ve 1881 'de Of'un bağlanmasıyla idari yapısı genişleyen Rize merkezli Lazistan sancağ1, 18 Haziran 1920'de müstakil bir sancak olmuştur. ${ }^{2} 1921$ 'de sancağın sınırlarında yeniden bir genişleme yaşanmış; 1878'den itibaren hem Lazistan hem de Rize adıyla anılmaya başlanması nedeniyle resmi yazışmalarda karışıklığı önlemek ve halkın daha çok Rize adını kullanmasından dolayı Kasım 1923'te sancağın adının Rize olmasına karar verilmiştir. ${ }^{3}$ Rize, 20 Nisan 1924'te vilayet olmuştur. ${ }^{4}$ Vilayet olduğunda Rize, Merkez, Hopa ve Atina kazaları ile bunlara bağlı sekiz nahiyeden oluşmaktaydı. 1926'da Merkez kaza 32 mahalle ve 169 köyden oluşan vilayetin yüzölçümü 1928 yılında 4.590 kilometrekare idi. ${ }^{5}$

1 Başbakanlık Osmanlı Arşivi (BOA), Şura-yı Devlet, 1830/27, 23 Aralık 1878.; Mehmet Okur-Veysel Usta, "Karadeniz Bölgesi Demografik Yapısına Dair Bir İnceleme”, History Studies, Volume:1/1, 2009, s.40.

2 Başbakanlık Cumhuriyet Arşivi (BCA), Fon: 030.18.1.1, Yer: 1.4.5, 18 Haziran 1920.

3 BCA, Fon:030.11.1.1, Yer: 1.5.7, 26 Kasim 1923.

4 "Rize", Yurt Ansiklopedisi, Cilt:9, İstanbul, 1982-83, s. 6362.

5 Sinan Başaran, “Cumhuriyet Dönemi Rize İdare Tarihi”, Türk İdare Dergisi, Sayı:486, Haziran 2018, s.52.; Rize ilinin idari tarihi ve 1930'lardan sonrası için ayrıca bkz. Orhan Naci Ak, Rize’nin Yönetim Tarihi, Rize 2008, Ali Taşpınar, Rize Tarihi, Rize 2004, Abdullah Battal Taymas, Yeşil Rize ve İli, Ankara 1950, 1967 Rize İl Yıllığı, Ankara, 1968; İhsan Topaloğlu, Bölge Tarihinde Rize, Topaloğulları Kültür Dayanışma Derneği Yayını, Trabzon, 1998.; Volkan Aksoy, “1933-50 Yılları Arasında Rize’nin İdari Teşkilatlanması”, Cumhuriyet Döneminde Rize I, RTEÜ Yayını, 2018, s.91. 


\section{Rize Vilayetinin Coğrafi Durumu}

Rize vilayeti hakkında bilgi veren $1925-26,26-27,27-28$ ve 28-29 yıllarına ait devlet salnamelerinde ${ }^{6}$ Rize'nin coğrafi olarak doğuda Gürcistan cumhuriyeti ve Artvin vilayeti, batıda Trabzon vilayeti güneyde Erzurum vilayeti ve kuzeyde Karadeniz ile çevrili olduğu ve il sınırlarının uzunluğunun batı hududunda bulunan Kalapotamoz ${ }^{7}$ deresinden Gürcistan hududuna kadar sahili takiben 165 kilometre olduğu bilgisine yer verilmektedir. ${ }^{8}$ Rize ilinin iklim durumuna ilişkin ise doğudan batıya doğru uzanan Anadolu kuzey dağlarının son derece meyilli bir yapıyla Karadeniz'e doğru uzandığı ve bu nedenle ziraate elverişli geniş düzlüklerin oluşmadığı ifade edilmektedir. Vilayetin iklimi ${ }^{9}$ başlıca iki kısma ayrılmakta olup, bilhassa yüksek kısımlarda kışın yağan kar 4-5 metreye kadar yükselir ve yağmurlar daha çoktur. Vilayet dahilinde Ardeş ${ }^{10}$ deresi ile Kalapotamoz dereleri büyüktür; yüksek dağların tepesinde alabalıkları olan birkaç adet küçük göller ve vilayetin hemen her tarafinda akarsular bulunmaktadır. ${ }^{11}$ Rize'de bulunan kuzey Anadolu dağ silsilesi içinde yer alan Kaçkarlar'ın yükseklikleri ile ilgili salnamelerde her hangi bir bilgiye rastlanmamaktadır.

\section{Rize Vilayetinin Tarihçesi, İdari Durumu ve Mülki İdare Memurları}

Rize vilayeti yüksek dağlarla Anadolu' dan ayrılarak hayatını karadan ziyade denizden kazanan ve coğrafi açıdan ne kadar zengin ise tarihi ve asar-1 atika açısından o derece fakir bir yer olarak tasvir edilmektedir. Bölgenin eskiçağlarına ait herhangi bir bilgi bulunmadığ1 ancak ortaçağlardan itibaren bilgilerin elde edildiği ve Trabzon'un ele geçirilmesinden sonra bölgenin de Türklere tabi hale geldiği belirtilmektedir ${ }^{12}$ Bölgede eski zamanlardan kalan eserler arasında Bozukkale mevkiindeki kale kalıntıları dikkat çekmektedir. Ayrıca, ilk defa Cafer Paşa namında bir zatın 974'te Mapavri'de ${ }^{13}$ Taş Camii denilen minaresiz bir cami ve yine 979'da Rize'de Kubbeli cami olarak bilinen Küçük Minareli cami ve Cezayirli Ali Paşa tarafından 1120 tarihlerinde yaptırılan Çarşı başındaki cami ve şehir dahilinde denize akan beş altı dere üzerinde güzel kemerli taş köprüler Türklerin bu bölgede bırakmış oldukları önemli eserler olarak sıralanmaktadır. ${ }^{14}$

6 Salnamelerle ilgili olarak bkz. Bilgin Aydın, "Salname”, TDV İslam Ansiklopedisi, Cilt:36, 2009.

7 Bugünkü İyidere.

8 Türkiye Cumhuriyeti Devlet Salnamesi 1925-1926, Matbaa-i Amire, İstanbul,1926, s.631.; 1926-27, s.876.; Rize'nin coğrafi durumuyla ilgili ayrıntılı bir çalışma için bkz. Pınar Polat, "Rize'nin Coğrafi Durumu", Cumhuriyet Döneminde Rize I, RTEÜ Yay., Rize, 2018, s.23-72.

9 Vilayetin iklimi ile igili ayrıntılar için bkz. Pınar Polat-Murat, "Rize’nin İklim Özellikleri ve Rize Çevresinde Uzun Dönem Sicaklık ve Yağış Verilerinin Trend Analizleri”, Fırat Üniversitesi Sosyal Bilimler Dergisi, Cilt: 27, Say1:1, 2017, s.1-23.

10 Bugünkü Ardeşen.

11 Türkiye Cumhuriyeti Devlet Salnamesi 1926-27, s.876.; Türkiye Cumhuriyeti Devlet Salnamesi 1927-28 , s.902.

12 Salnamede, bölgede Türk hakimiyeti ile ilgili şu bilgiler yer almaktadır: "Trabzon Rum hükümeti Rize ve Hemşin havalisini de ihtiva eylediği sıralarda İslam orduları Ermeni arazisini istila edince onların bakiyyetül süyufu şimale doğru atılarak Rize vilayetinin bakir ormanlarl ile örtülmüş olan şimale müteveccih yüksek dağlarına iltica eylemişlerdi. Bilahare İstanbul'u zapt eden Türkler kuvvetli bir donanma ve kudretli bir ordu ile Trabzon Rum hükümetini bila muharebe teslime mecbur edince Rize ve Hemşin dahi tabi bulunduğu hükümet gibi muharebesiz Türklerin tabiiyetini kabul eylemistir." Türkiye Cumhuriyeti Devlet Salnamesi 1926-1927, Matbuat Müdüriyet-i Umumiyesi, İstanbul, 1927, s.878.

13 Bugünkü Çayeli.

14 Türkiye Cumhuriyeti Devlet Salnamesi 1926-27, s.878. 
Vilayetin idari durumu hakkında Rize vilayeti merkez kazası ile Atina ve Hopa kazalarından oluştuğu bilgisi yer almaktadır. ${ }^{15}$ Cumhuriyet' in ilan edildiği tarihte Rize liva (sancak) merkeziyken, 1924 yılında Pazar (Atina), Hopa ve Merkez kazadan oluşan bir vilayete dönüştürülmüştü. ${ }^{16}$ Rize Merkez kazası Merkez, Kura-1 Seba (İkizdere, nahiye merkezi:Çağırankaya), Karadere (Kalkandere, nahiye merkezi: Medrese) ve Mapavri (Çayeli, nahiye merkezi: Yenipazar) nahiyelerinden; Atina kazası Merkez, Ardeşen ve Hemşin nahiyelerinden; Hopa kazası ise Merkez, Arhavi, Kemalpaşa ve Viçe (Fındıklı) nahiyelerinden oluşuyordu. ${ }^{17}$ Salnamelere göre, Rize merkez kazasının 32 mahallesi ve Mapavri (Yenipazar), Karadere( Medrese) Kura-yı seba (Çağırankaya) nahiyeleri vardır. Merkezde 84, Mapavri nahiyesinde 33, Karadere nahiyesinde 23 ve Kura-y1 seba nahiyesinde 27 olmak üzere toplam 169 karyesi; Atina kazasının Ardeş ve Hemşin (Sazviran) nahiyeleriyle, Atina merkez kazasının 43, Ardeş nahiyesinin 25, Hemşin nahiyesinin 33 olmak üzere toplam 101 karyesi; Hopa kazasının Arhavi, Viçe, Kemal Paşa nahiyeleriyle, Hopa merkez kazasının 17, Arhavi nahiyesinin 26, Viçe nahiyesinin 17, Kemalpaşa nahiyesinin 19 olmak üzere toplam 79 karyesi mevcuttur. Rize vilayetinin merkez kazasıyla birlikte 3 kazası ve bunlara bağlı 8 nahiye ile 349 karyesi bulunmaktadır. ${ }^{18}$

Rize vilayetindeki mülki idare memurlarının listeleri de salnamelerde verilen bilgiler arasındadır. Bu bilgiler çerçevesinde memurlar ve görevleri aşağıdaki tablolarda gösterilmiştir.

\[ \begin{array}{r}1925-26 \text { Devlet Salnamesine Göre Memurların Ísimleri } \\
\text { Rize-Merkez kazast: }{ }^{19}\end{array} \]
\begin{tabular}{|l|l|}
\hline Merkez-Memuriyet & Ismi \\
\hline Vali & Mehmet Hurşit Bey \\
\hline Muhasebeci & Muhsin Bey \\
\hline Tahrirat Müdürü & Mümtaz Bey \\
\hline Müftü & Nuh Efendi \\
\hline Mahkemei Asliye Cinayet Reisi & Arif Bey \\
\hline Mahkemei Asliye Cinayet Müddei Umumisi & Rıfat Bey \\
\hline Mahkemei Asliye Azası & Salim Bey \\
\hline Mahkemei Asliye Azast & Hulusi Bey \\
\hline Mahkemei Asliye Azast & Hayri Bey \\
\hline Mahkemei Asliye Azast & Hüsnü Bey \\
\hline Mahkemei Asliye Aza Mülazımı & Ismail Bey \\
\hline
\end{tabular}

15 Türkiye Cumhuriyeti Devlet Salnamesi 1926-27, s.879.; Türkiye Cumhuriyeti Devlet Salnamesi 19271928, Matbuat Müdüriyet-i Umumiyesi, İstanbul, 1928, s.902.; Türkiye Cumhuriyeti Devlet Y1llı̆̆1 19281929, Devlet Matbaası, İstanbul, 1929, s.508.; Vilayetin idari yapısıyla ilgili ayrıntılar için bkz. Rahmi Çiçek, "Rize'nin İdari Yapısı", Cumhuriyet Döneminde Rize I, RTEÜ Yay., Rize, 2018, s.72-77; Sinan Başaran, "Cumhuriyet Dönemi Rize İdare Tarihi”, s.51-52.; Orhan Naci Ak, Rize’nin Yönetim Tarihi, Çınar Deneği Yay., Rize 2008.

16 Mesut Çapa, “Rize’nin Yakın Tarihine Bir Bakış”, Karadeniz İncelemeleri Dergisi, Sayı: 20, 2016, s.295.

17 Mesut Çapa, a.g.m., s.295.

18 Türkiye Cumhuriyeti Devlet Salnamesi 1926-27, s.879.; Türkiye Cumhuriyeti Devlet Salnamesi 1927-28 , s.902.; Türkiye Cumhuriyeti Devlet Y1llığ 1928-29, s.508.

19 Türkiye Cumhuriyeti Devlet Salnamesi 1925-26, s.632. 


\begin{tabular}{|l|l|}
\hline Mahkemei Asliye Müddei Umumisi & Tahsin Bey \\
\hline Mahkemei Asliye Azası & Ahmet Hamdi Bey \\
\hline Mahkemei Asliye Azası & Ali Rıza Bey \\
\hline Mahkemei Asliye Aza Mülazımı & Osman Nuri Bey \\
\hline Birinci Müstantık & Ömer Bey \\
\hline İkinci Müstantık & Cemal Bey \\
\hline Jandarma Kumandanı & - \\
\hline Slhhiye Müdürü & Tevfik Bey \\
\hline Muhasebei Hususiye Mdürüu & Hakkı Bey \\
\hline Tapu Müdürü & Abdülkerim Bey Bey \\
\hline Nüfus Müdürü & Mehmet Hulusi Bey \\
\hline Muhasebe mümeyyizi & Mustafa Bey \\
\hline Varidat mümeyyizi & Mehmet Bey \\
\hline Belediye Reisi & Hakkı Bey \\
\hline
\end{tabular}

1925-26 Devlet Salnamesinde yer aldığı şekliyle Rize'nin 20 Nisan 1924'te ${ }^{20}$ vilayet olmasının ardından vali Mehmet Hurşit Bey (Akkaya) olmuştur. ${ }^{21} 13$ Eylül 1923 'te Lazistan mutasarrıfı olarak göreve başlayan ve ardından Rize valisi olan Mehmet Hurşit Bey, 1926 yılına kadar bu görevde kalmıştır. ${ }^{22}$

1926-27 Devlet Salnamesine Göre Memurların İsimleri

Rize Vilayeti: ${ }^{23}$

\begin{tabular}{|l|l|}
\hline Memuriyet & Ísim \\
\hline Vali & Eşref Bey \\
\hline Muhasebeci & Muhsin Bey \\
\hline Tahrirat Müdürü & Salahaddin Bey \\
\hline Müftü & Nuh Efendi \\
\hline Müstakil Cinayet Mahkeme Reisi & Fevzi Bey \\
\hline Müstakil Cinayet Mahkeme Müddei Umumiyesi & Rıfat Bey \\
\hline Müstakil Cinayet Mahkeme Azası & Hulusi Bey \\
\hline Müstakil Cinayet Mahkeme Azası & Hayrullah Bey \\
\hline Müstakil Cinayet Mahkeme Azası & Fazlı Bey \\
\hline Müstakil Cinayet Mahkeme Azası Mülazımı & Ísmail Hakkı Bey \\
\hline Müstakil Cinayet Mahkeme Azası Mülazımı & Suphi Bey \\
\hline Mahkemei Asliye Reisi & Osman Bahri Bey \\
\hline Mahkemei Asliye Müddei Umumisi & Tahsin Bey \\
\hline Mahkemei Asliye Azası & Salih Fevzi Bey \\
\hline
\end{tabular}

20 "Rize", Yurt Ansiklopedisi, Cilt:9, s.6362.

21 Sinan Başaran, "Valiler", Cumhuriyet Döneminde Rize I, RTEÜ Yayını, 2018, s.105.

22 Sert mizacından dolayı halk tarafından "Deli Hurşit” olarak da adlandırılan Mehmet Hurşit Bey 1953’te hayatını kaybetmiştir. Başaran, "Valiler”, s.106.; Rize 1967 İl Yıllığı, s.29.

23 Türkiye Cumhuriyeti Devlet Salnamesi 1926-27, s.884. 


\begin{tabular}{|l|l|}
\hline Mahkemei Asliye Azası Mülazımı & Ömer Bey \\
\hline Birinci Mustantık & Nizameddin Bey \\
\hline İkinci Mustantık & Cemal bey \\
\hline Jandarma Kumandanı & Yusuf Bey \\
\hline Sihhiye Müdürü & Musa Kazım Bey \\
\hline Tapu Müdürü & Vahid Bey \\
\hline Nüfus Müdürü & Mehmet Hulusi Bey \\
\hline Posta ve Telgraf Müdürü & Hasan Lemi Bey \\
\hline Muhasebe Mümeyyizi & Mustafa Bey \\
\hline Varidat Mümeyyizi & Mehmet Bey \\
\hline Baytar Müfettişi & Salim Suphi Bey \\
\hline Belediye Reisi & Halil Bey \\
\hline
\end{tabular}

1926-27 Devlet salnamesinde vali olarak Eşref Bey görülmektedir. 1921-22 yılları arasında Lazistan mutasarrıflığına atanan Mehmet Eşref Bey (Sayit) ${ }^{24} 3$ Mart 1926' da Rize valisi oldu. $^{25}$

\section{7-28 Devlet Salnamesine Göre Memurların İsimleri}

Rize Vilayeti memurlar listesi: ${ }^{26}$

\begin{tabular}{|l|l|}
\hline Memuriyet & Isim \\
\hline Vali & Eşref Bey \\
\hline Muhasebeci & Muhsin Bey \\
\hline Tahrirat Müdürü & Behçet Bey \\
\hline Müftü & Nuh Efendi \\
\hline Ăgır Ceza Dairesi Reisi & Hüseyin Fevzi Bey \\
\hline Ăgır Ceza Müddei Umumisi & Asım Bey \\
\hline Muavin & Hulusi Bey \\
\hline Aza & Suphi Bey \\
\hline Aza & Hayrullah Bey \\
\hline Aza Mülazımı & Faik Bey \\
\hline Hukuk Hakimi & Osman Bahri Bey \\
\hline Ceza Hakimi & Mehmet Fazlı Bey \\
\hline Ser Müstentik & Nizameddin Bey \\
\hline İkinci Müstentik & Cemal Bey \\
\hline Jandarma Kumandanı & Mustafa Bey \\
\hline Sihhiye ve Muaveneti İçtimaiye Müdürü & Musa Kazım Bey \\
\hline Merkez Hükümet Tabibi & - \\
\hline Muhasebe-i Hususiye Müdürü & Hüsnü Bey \\
\hline Sihhiye ve Muaveneti İçtimaiye Müdürü & Musa Kazım Bey \\
\hline
\end{tabular}

24 BCA, Fon:30.18.1.1, Yer:3.16.3.

251948 yılında vefat etmiştir. Başaran, "Valiler", s.106.

26 Türkiye Cumhuriyeti Devlet Salnamesi 1927-28, s.910. 


\begin{tabular}{|l|l|}
\hline Nüfus Müdürü & Mehmet Hulusi Bey \\
\hline Tapu Müdürü & Vahid Bey \\
\hline Evkaf Müdürü & Tahir Bey \\
\hline Ziraat Müdürü & Kemal Bey \\
\hline Baytar Müdürü & Salim Suphi Bey \\
\hline Posta ve Telgraf Müdürü & Hasan Lemi Bey \\
\hline Belediye Reisi & Hakk Bey \\
\hline
\end{tabular}

1927-28 yılı Devlet Salnamesinde de vali olarak yine Eşref Bey'in adı görünmektedir. Eşref Bey valilik görevini 26 Ekim 1927'ye kadar sürdürmüştür. ${ }^{27}$

1928-29 Devlet Salnamesine Göre Memurların İsimleri
Rize vilayeti memurlarl:28


1928-29 Devlet Salanmesine göre Cemil Bey, Rize valisi olarak görünmektedir. Mehmet Cemil Bey (Berkmen) 15 Ekim 1927'de Rize valisi olmuştur. ${ }^{29}$

1925-29 arasındaki devlet salnamelerinde ayrıca vilayet dahilinde işlenen adli suçlara ait de bilgiler bulunmaktadır. Bu bilgilere göre, 1925 y1lında 411, 1926'da 128, 1927'de 259,1928 'de 222 adet adli suçun işlenmiş olduğu anlaşılmaktadır. ${ }^{30}$ Rize vilayetinde adli teşkilatın öncelikle asliye mahkemeleri çerçevesinde şekillendiği görülmektedir. Sulh mahkemesinin ve cinayet mahkemesinin ise 1927 sonrasında oluşturulduğu anlaşılmaktadır. 1925 yılında Rize milletvekillerinden Esat Bey (Özoğuz) vermiş olduğu bir takrirde Rize'de ayrı bir cinayet mahkemesinin kurulmasının zorunluluğunu dile getirmiştir. ${ }^{31}$

\section{Rize Vilayetinin Nüfusu}

1926-27 Devlet salnamesine göre Rize vilayeti merkez kazasının genel nüfusu 133.059 kişi olarak görülmektedir. Atina kazasında 55.693, Hopa kazasında 43.428 olmak üzere il genelinde toplam nüfus 232.180 olarak verilmektedir. ${ }^{32}$ Ayrıca ildeki doğum-ölüm ve evlenme-boşanma oranları da salnamede verilen bilgiler arasındadır. Doğum-ölüm oranları karşılaştırıldığında, Rize merkez kazasında doğum oranında erkek nüfusun kadın nüfustan daha fazla olduğu, benzer şekilde ölüm oranında da erkek nüfusun önde olduğu görülmektedir. Diğer kazalarda da bu oranlar aşağı-yukarı benzerlik göstermektedir. Evlenme-Boşanma oranlarına bakıldığında ise, Rize merkez kazasının diğer kazalara oranla daha önde olduğu anlaşılmaktadır. Bu farkın nedeni merkez kaza nüfusunun diğerlerinden yüksek olmasından kaynaklanmaktadır. 1926-27 devlet salnamesine göre ilin nüfus durumu aşağıdaki tablolarda verilmiştir.

1926-27/Rize Vilayetinin Nüfusu 33

\begin{tabular}{|l|r|r|r|r|r|}
\hline & \multicolumn{2}{|c|}{ Yeni Kaylt } & \multicolumn{2}{l|}{ Genel Nüfus } & \multicolumn{2}{l|}{ Genel Nüfus Toplamı } \\
\cline { 2 - 6 } & Kadın & Erkek & Kadın & Erkek & Kadın ve Erkek \\
\hline Merkez Rize Kazası & 36 & 3 & 68.980 & 64.089 & 133.059 \\
\hline Atina Kazast & 4 & 2 & 28.909 & 26.784 & 55.693 \\
\hline Hopa Kazası & 27 & 6 & 22.146 & 21.282 & 43.428 \\
\hline Rize Vilayeti Toplamı & 67 & 11 & 120.035 & 112.445 & 232.180 \\
\hline
\end{tabular}

29 1944’te hayatını kaybetmiştir. Başaran, "Valiler”, s.107.;

30 Türkiye Cumhuriyeti Devlet Salnamesi 1925-26, s.631; Türkiye Cumhuriyeti Devlet Salnamesi 1926-27, s.878; Türkiye Cumhuriyeti Devlet Salnamesi 1927-28, s.909; Türkiye Cumhuriyeti Devlet Y1llığ 1 192829, s.515.

31 Mustafa Arıkan, "Rize Adliyesi ve Arşivi”, Cumhuriyet Döneminde Rize I, RTEÜ Yayını, 2018, s.186.

32 Türkiye Cumhuriyeti Devlet Salnamesi 1926-27, s.877.

33 Türkiye Cumhuriyeti Devlet Salnamesi 1926-27, s.877. 
1926-27-Doğum/Ölüm ve Evlenme/Boşanma Oranlart ${ }^{34}$

\begin{tabular}{|l|r|l|r|r|r|r|}
\hline & \multicolumn{1}{|l|}{ Boşanma } & Evlenme & \multicolumn{2}{|c|}{ Ölüm } & \multicolumn{2}{|c|}{ Dŏ̆um } \\
\cline { 2 - 8 } & Adet & Adet & Kadın & Erkek & Kadın & Erkek \\
\hline Merkez Rize Kazası & 58 & 860 & 86 & 213 & 1935 & 2396 \\
\hline Atina Kazast & 16 & 368 & 142 & 257 & 699 & 708 \\
\hline Hopa Kazast & 15 & 268 & 24 & 84 & 266 & 277 \\
\hline Rize Vilayeti Toplamı & 89 & 1496 & 252 & 554 & 2900 & 3376 \\
\hline
\end{tabular}

1927-28 devlet salnamesinde de ilin nüfusuna ait bilgilere bulunmaktadır. Buna göre, kayıtlı genel nüfus merkez kazada 99.720, Atina'da 41.626, Hopa kazasında 30.317 olmak üzere Rize genelinde 171.663 kişidir. ${ }^{35}$ Bir önceki yıl ile karşılaştırıldığında Rize nüfusunda bir azalmanın meydana geldiği anlaşılmaktadır. Doğum-ölüm oranlarına bakıldığında erkek nüfusun daha yüksek olduğu görülmektedir ancak burada bir istisna olarak Hopa kazasında kadın nüfusun doğum oranı daha fazladır. Ölüm oranları ise, bir önceki yılda olduğu gibi erkek nüfusta daha fazladır. 1927-28 devlet salnamesine göre ilin nüfus durumu aşağıdaki tablolarda verilmiştir.

1927-28/Rize Vilayeti Boşanma/Evlenme ve Ölüm Oranlarl: ${ }^{36}$

\begin{tabular}{|l|r|r|r|r|r|}
\hline \multirow{2}{*}{ Kazalar } & Boşanma & \multirow{2}{*}{ Evlenme } & \multicolumn{4}{|c|}{ Ölüm } \\
\cline { 4 - 6 } & & & Kadın & Erkek & Toplam \\
\hline Rize & 27 & 353 & 104 & 210 & 314 \\
\hline Atina & 13 & 171 & 40 & 125 & 165 \\
\hline Hopa & 19 & 174 & 43 & 148 & 191 \\
\hline Toplam & 59 & 298 & 187 & 483 & 670 \\
\hline
\end{tabular}

1927-28/Rize Vilayeti Nüfusu/Doğum oranlart: ${ }^{37}$

\begin{tabular}{|l|r|r|r|r|r|r|}
\hline \multirow{2}{*}{ Kazalar } & \multicolumn{3}{|c|}{ Doğum } & \multicolumn{3}{c|}{ Kaytlı Genel Nüfus } \\
\cline { 2 - 7 } & Kadın & Erkek & Toplam & Kadın & Erkek & \multicolumn{1}{l|}{ Toplam } \\
\hline Rize & 843 & 971 & 1714 & 57.159 & 14.561 & 99.720 \\
\hline Atina & 29 & 344 & 634 & 25.311 & 16.315 & 41.626 \\
\hline Hopa & 409 & 345 & 754 & 16.249 & 14.068 & 30.317 \\
\hline Toplam & 1542 & 1660 & 3202 & 99.719 & 71.944 & 171.663 \\
\hline
\end{tabular}

37 Türkiye Cumhuriyeti Devlet Salnamesi 1927-28, s.909. 
1927 yılına ait Başvekalet İstatistik Umum Müdürlüğ̈̈ verilerinde Rize vilayeti kadın ve erkek nüfusunun toplam nüfusa oranlart şu şekilde verilmektedir.: ${ }^{38}$

\begin{tabular}{|l|r|r|r|}
\hline \multirow{2}{*}{ Kazalar } & \multicolumn{3}{|c|}{$\%$ Oranı } \\
\cline { 2 - 5 } & Kadın & Erkek & Toplam \\
\hline Rize & $\% 41.7$ & $\% 58.3$ & 100 \\
\hline Atina & $\% 60.8$ & $\% 39.2$ & 100 \\
\hline Hopa & $\% 53.6$ & $\% 46.4$ & 100 \\
\hline Toplam Nüfus & $\% 58.1$ & $\% 41.9$ & 100 \\
\hline
\end{tabular}

1928-29 Devlet Salnamesine göre ise ilin kayıtlı genel nüfusu merkez kazada 99.724, Atina'da 41.626, Hopa'da 30.317 ve genel toplam 171.667 kişi olarak verilmektedir. ${ }^{39} \mathrm{Bu}$ salnamede yer alan nüfus verilerinin bir önceki yıl ile benzerlik göstermesi dikkat çekicidir. Doğum-ölüm oranlarına göre, yine erkek nüfusun daha fazla doğum ve ölüm oranına sahip olduğu görülmekle birlikte istisna olarak Hopa kazasında erkek nüfusun doğum oranı kadın nüfustan daha azdır. Evlenme-boşanma oranlarına bakıldığında ise evlenme oranlarının daha yüksek olduğu anlaşılmaktadır. Hopa kazasında 1928-29 döneminde boşanma vuku bulmamıştır. 1921928-29 devlet salnamesine göre ilin nüfus istatistikleri aşağıdaki gibidir.

1928-29/Rize Vilayeti Genel Nüfus/Doğum/Ölüm oranlart: ${ }^{40}$

\begin{tabular}{|l|r|r|r|r|r|r|r|r|r|}
\hline \multirow{2}{*}{ Kazalar } & \multicolumn{3}{|c|}{ Kayıtlı Genel Nüfus } & \multicolumn{4}{c|}{ Doğum } & \multicolumn{3}{c|}{ Ölüm } \\
\cline { 2 - 11 } & Erkek & Kadın & Toplam & Erkek & Kadın & Toplam & Erkek & Kadın & Toplam \\
\hline Rize & 41.565 & 58.159 & 99.724 & 1.663 & 1.271 & 2.934 & 665 & 356 & 1.021 \\
\hline Atina & 16.315 & 25.311 & 41.626 & 428 & 345 & 773 & 235 & 95 & 330 \\
\hline Hopa & 14.068 & 16.249 & 30.317 & 607 & 647 & 1.254 & 163 & 82 & 245 \\
\hline Toplam & 71.948 & 99.719 & 171.667 & 2.698 & 2.263 & 4.961 & 1.063 & 533 & 1.596 \\
\hline
\end{tabular}

1928-29/Rize Vilayeti Evlenme/Boşanma oranlart: ${ }^{41}$

\begin{tabular}{|l|r|r|r|r|}
\hline \multirow{2}{*}{ Kazalar } & \multicolumn{3}{|c|}{ Evlenme } & Boşanma \\
\cline { 2 - 5 } & Erkek & \multicolumn{1}{|c|}{ Kadın } & \multicolumn{1}{|c|}{ Toplam } & \\
\hline Rize & 813 & 813 & 1.626 & 16 \\
\hline Atina & 254 & 254 & 508 & 14 \\
\hline Hopa & 378 & 378 & 756 & 0 \\
\hline Toplam & 1.445 & 1.445 & 1.890 & 30 \\
\hline
\end{tabular}

1925-29 yılları arasındaki devlet salnamelerine göre Rize vilayetinin genel nüfusunun tablolarda gösterilenlerden daha fazla olduğu düşünülmektedir. Bunun nedeni olarak, ölüm, doğum, evlenme-boşanma gibi işlemlerin halk tarafından sağlıklı bir şekilde

38 Türkiye Nüfusu, Başvekalet İstatistik Umum Müdürlüğü, Yayın No:3, Ankara, 1928, s.24.; Nüfusla ilgili ayrıntılar için bkz. İsmail Özdoğan, Rize Sosyal, Siyasal ve Ekonomik Yapısı, Yayınlanmamış Yüksek Lisans Tezi, Muğla Üniversitesi SBE, Muğla, 2004, s.37-38.

39 Türkiye Cumhuriyeti Devlet Y1llı̆̆1 1928-29, s.509.

40 Türkiye Cumhuriyeti Devlet Yıllığı 1928-29, s.509.

41 Türkiye Cumhuriyeti Devlet Yillığı 1928-29, s.509. 
nüfusa bildirilmemesi yanı sıra, vilayetin ekonomik durumunun zayıflığ gösterilmektedir. ${ }^{42}$ Diğer yandan, Rize'nin aile yapısı ve coğrafyanın getirdiği zorluklar nedeniyle nüfus sayımlarında eksikler oluşması mümkündür. ${ }^{43}$ Nitekim tablolarda yer alan "kayıtlı" nüfus bölümü, kayıtlı olmayan bir nüfusun varlığına işaret etmektedir. Ayrıca ölüm oranlarında erkek nüfusun daha fazla olduğu görülmekle birlikte doğum oranlarında da yine erkek nüfusun fazla olduğu anlaşılmaktadır.

Rize vilayeti nüfusuyla ilgili verilere bakıldığında doğum oranlarında yıllar içinde bir artış sözkonusudur. Bu artışta ailelerin çok çocuk sahibi olma düşüncesi ve bunun da yol vergisinden muaf olma düşüncesinden kaynaklandığg düşünülmektedir. ${ }^{44}$ Dikkat çeken bir başka husus ise genel nüfus ortalaması dikkate alındığında Rize nüfusunun artış hızının yavaş olduğu görülmektedir. Bunun ise yine ekonomik sebeplerden dolayı vilayetten dışarıya yapılan göçlerden kaynaklanması muhtemeldir.

\section{Rize Vilayetinin Ziraat-Ticaret Durumu}

Rize'de özellikle iktisadi açıdan gelir getirebilecek ürünlerin dikimine öncelik verilmiş ve 1922 yılında çay ve mandalina fidanlığı kuran Ziraat Müdürü Zihni Derin'in burada yetiştirdiği fidanları halka dağıtmasıyla vilayette portakal ve mandalina ziraati yaygınlaşmıştır. ${ }^{45}$ Rize, arazi ve iklim özellikleri açısından her çeşit tarıma elverişli değildir. Rize'de tarımsal faaliyetlere çok uygun bir alan olmadığ 1 yerinde gözlemlenerek 1924 yılında Atatürk tarafından da dile getirilmiştir. Rize'de özellikle çay, portakal, mandalina ve fındık üretiminin ağırlıkta olduğunu ayrıca, mısır, arpa, buğday, fındık, pirinç, fasulye, keten, kenevir üretiminin yanında, kıyı bölgelerde balıkçılık, iç bölgelerde ise hayvancılık yapıldığı görülmektedir. ${ }^{46}$ Ancak ildeki mısır, fasulye, patates gibi zirai rünlerin üretim miktarları ilin ihtiyaçlarını karşılamaya yetmemektedir. ${ }^{47}$

Vilayetin ziraat durumuyla ilgili 1925-26 devlet salnamesinde Rize merkez kazasının 150 bin dönüm arazide ziraat yapıldığı; 260 bin dönüm arazinin ise ziraat dış1 olduğu bilgisine yer verilmektedir. ${ }^{48}$ Atina kazasında ziraate elverişli 88 bin 600, Hopa' da ise 3 bin 600 dönüm arazi bulunduğu belirtilmektedir. Merkez kazada 11 milyon kilo mısır, 1 milyon kilo arpa, 1 milyon kilo fasulye, 100 bin kilo tütün, 450 bin kilo patates, 20 bin kilo kendir, 70 bin kilo findik, 35 milyon adet portakal, 700 bin kilo elma, 500 bin kilo armut, 40 bin kilo ceviz, 15 bin kilo kestane üretilmekte olup, bunlardan 400 bin kilo fasulye, 50 bin kilo tütün, 10 bin kilo kendir bezi, 50 bin kilo findık, 30 milyon adet portakal, 500 bin kilo elma,

42 Sinan Başaran, "Cumhuriyet Dönemi Rize Nüfusu", Fırat Üniversitesi Sosyal Bilimler Dergisi, Cilt:30, Say1:1, 2020, s.487.

43 Sinan Başaran, "Cumhuriyet Dönemi Rize Nüfusu”, s.490.

44 Sinan Başaran, "Cumhuriyet Dönemi Rize Nüfusu”, s.492.

45 Mesut Çapa, "Rize’nin Yakın Tarihine Bir Bakış”, s.303.

46 Songül Alşan, "Rize'de Ziraat, Balıkçılık ve Hayvancılık (1923-50)", Karadeniz İncelemeleri Dergisi, Sayı:27, 2019, s.188.; Ayrıca ilin iktisadi durumuna dair ayrıntılar için bkz. Elif Yormaz, Rize Gazetesine Göre Rize'de Sosyo-Ekobomik ve Kültürel Hayat, Yayınlanmamış Yüksek Lisans Tezi, KTÜ SBE, Trabzon, 2016.

47 Özlem Yıldırım, “"Cumhuriyet Döneminde Rize'de Tarım, Hayvancılık ve Ticaret”, Cumhuriyet Döneminde Rize I, RTEÜ Yayını, 2018, s.220.

48 Türkiye Cumhuriyeti Devlet Salnamesi 1925-26, s.630. 
10 bin kilo armut, 10 bin kilo ceviz, 5 bin kilo kestane ihraç edilmektedir. ${ }^{49}$ Hopa kazasında 12 milyon kilo mısır 3 milyon kilo findık, bin kilo tütün ve 5 milyon kilo elma üretilmekte ve bunun büyük kısmı ihraç edilmektedir. ${ }^{50}$ Atina kazasında ise toplamda 3 milyon 470 bin 600 kilo miktarında buğday, arpa, keten, kendir, ceviz, ve tütün istihsal edilmektedir. Bunlardan 300 bin kilo misir, 30 bin kilo fasulye, 14 bin 620 kiyye yağ, 1 milyon adet portakal, 16 bin 226 kilo findık, 500 kilo ceviz, 10 bin kilo tütün ihraç edilmektedir. ${ }^{51} 1925$ senesi Rize vilayetinin merkez kazasının genel geliri 82 bin 812 lira, Atina kazasının 49 bin 788 lira, Hopa kazasının ise 57 bin 701 liraydı. Belediyenin geliri ise Merkezde 16 bin, Hopa'da 6 bin 463, Atina'da ise 3 bin 106 lirayd..$^{52}$

1926-27 devlet salnamesinde Vilayetin ziraat durumuna dair kızılağaçlık ve çalılık halindeki arazi de dahil olmak üzere toplam ziraate elverişli 440 bin dönüm arazi olduğu belirtilmektedir. ${ }^{53}$ Bir önceki yıla göre ziraate elverişli arazi miktarında önemli ölçüde artış olduğu gözlemlenmektedir. Salnameden bu arazide 110 bin dönüm mısır ve fasulye, 10 bin dönüm arpa, 500 dönüm kenevir, 500 dönüm tütün, 150 dönüm pirinç ve 8850 dönüm değişik türde sebze ve 20 bin dönümde de ağaç yetiştirildiği ve bu arazilerden 14 milyon 300 bin kilo misir, 750 bin kilo fasulye, 1 milyon kilo arpa, 30 bin kilo tütün, 30 bin kenevir, 9 bin kilo pirinç, 30 milyon adet portakal ve mandalina ve emsali 100 bin kilo kiraz, 10 bin kilo dut 10 bin kilo ceviz, 20 bin kilo kestane, 10 bin karayemiş, 500 bin kilo taze fasulye, 25 bin kilo domates, 50 bin adet patlıcan, 500 bin kilo kabak, 400 bin karalahana hasat edildiği anlaşılmaktadır. ${ }^{54}$ 1926-27 salnamesinde bir önceki yıldan farklı olarak vilayette bulunan büyük ve küçükbaş hayvan sayılarına da yer verilmiştir. Buna göre vilayette, 17 bin 647 inek, 8401 öküz ve tosun, 58 manda, 18 bin 062 koyun, 88 bin 043 keçi, 307 at, 158 kısrak, 46 eşek (merkep), 601 katırdır (ester) bulunmaktadır. ${ }^{55}$

Atina kazasında ise halkın başlıca gıdasının mısır olduğu ancak \%1 oranında pek az miktarda üretildiği ifade edilmektedir. Aşarın lağvından sonra kazada 3 milyon 40 bin kilo misır 100 bin kilo tütün, 65 bin kilo pirinç ve cüzi miktarda buğday, arpa, kendir ve keten üretilmiştir. Kazada bulunan 24 bin 832 toplam ehli hayvan sayısının 10 bin 607 inek, 696 öküz ve tosun, 37 manda, 8785 koyun, 4186 keçi, 206 at, 79 kısrak, 17 eşek, 216 katırdan oluştuğu görülmektedir. ${ }^{56}$

Hopa kazasında her çeşit sebze ve meyve yetiştiği; portakal, limon ve mandalinaya uygun olduğu ve portakal, elma ve findığın gelir kaynağı olduğu belirtilmektedir. Domates, fasulye, kabak, lahana, hıyar, patatesten başka sebzenin bilinmediği; enginar, semizotu, bakla, pırasa, 1spanak ve diğer sebzelerin hatta kavun, karpuzun hariçten getirildiği salnamede verilen bilgilerdendir. Fındık ve portakaldan sonra elma, ceviz, armut, dut, erik en çok ürün veren meyveler olup, kazada çoğunlukla mısır yetiştirilmektedir. Arazi dar olduğundan mısır üretimi yeterli değildir. Kemalpaşa'da (Makribal) oldukça iyi pirinç yetiştiği, ve siyah,

49 Türkiye Cumhuriyeti Devlet Salnamesi 1925-26, s.630.

50 Türkiye Cumhuriyeti Devlet Salnamesi 1925-26, s.630.

51 Türkiye Cumhuriyeti Devlet Salnamesi 1925-26, s.630.

52 Türkiye Cumhuriyeti Devlet Salnamesi 1925-26, s.631.

53 Türkiye Cumhuriyeti Devlet Salnamesi 1926-27, s.878.

54 Türkiye Cumhuriyeti Devlet Salnamesi 1926-27, s.878.

55 Türkiye Cumhuriyeti Devlet Salnamesi 1926-27, s.878.

56 Türkiye Cumhuriyeti Devlet Salnamesi 1926-27, s.880. 
renkli, kokulu koruksuz üzümünden pekmez yapıldığı bilgisi verilmektedir. Ziraate elverişli 17 bin 342 dönüm arazi olup, 8200 dönümünün ise elverişsiz olduğu ifade edilmektedir. Bahsedilen arazilerde 70 kilo buğday, 20 kilo arpa, 52 kilo fasulye, 900 kilo pirinç, 29 bin kilo misır, 300 kilo patates, 50 kilo soğan toplam 30 bin 342 kilo ziraat yapılmıştır. ${ }^{57}$ Kazadan geçen sene 2 milyon 640 bin 821 kilo kabuklu findık ile 476 bin 199 kilo elma ve 55 bin adet portakal ihraç edildiği söylenmektedir. Kazada koyun keçi gibi hayvanlar olsa da mera olmadığı için Artvin Ardahan meralarında hayvanların otlatıldığ 1 ve toplam hayvan miktarının 28 bin 545 olduğu belirtilmektedir. Diğer kazalardan farklı olarak Hopa'da tiftik keçisi yetiştirildiği anlaşılmaktadır. ${ }^{58}$ Salnameye göre, Hopa Kazasının geçen bir senelik gelirinin 171 bin 820 lira; Hopa liman gelirinin 2 bin 490 lira olduğu anlaşılmaktadır. Hopa rüsumat gelirleri 31 bin 517 lira; özel idarenin gelirleri ise 23 bin 128 liradır. Bunun 18 bin 638 lirası tuzdan, 156 lirası müskirattan ve 3325 lirası puldan, 797 lirası deniz avcılığından ve pösteki rüsumundan, 8 lirası nakit cezalardan ve 264 lirası balık avcılığından alınmıştır. Belediye gelirleri toplamı ise 14 bin 723 liradır. ${ }^{59}$

1926-27 devlet salnamesinde Hopa limanına dair ayrıntılı bilgiler verilmiştir. $\mathrm{Bu}$ bilgilere göre, Hopa limanına 1926 ocak ayından temmuz sonuna kadar yedi ay içinde 2 bin 194 ton ticari eşya ithal olunduğu; bunun 2 bin 117 tonu Türk limanlarından ve 87 tonu ecnebi limanlarından yapıldığı; bu süredeki ihracatın 893 ton olup, 478 tonu Türk limanlarına ve 415 tonu ecnebi limanlarına yapıldığı görülmektedir. Limana 7 ay içinde 2 bin 480 yolcu gelmiş, ve 3 bin 211 yolcu gitmiştir. ${ }^{60}$

1927-28 y1l1 devlet salnamesine göre ise, Rize vilayetinin 1372 kilometre kare arazisinin ziraate uygun, 3033 kilometre karesinin ise ziraate elverişli olmadığ anlaşılmaktadır. Ziraate elverişsiz arazinin 1843 kilometrekaresinin dağlık ve taşlık ve 500 kilometrekaresinin ise göl, bataklık ve meralık olduğu belirtilmektedir. ${ }^{61}$ Vilayette üretilen ürünler ve bunların hasatlarının miktarına yer verilmiştir. Bu miktarlar aşağıdaki tablolarda gösterilmektedir.

1927-28 Yllı-Rize'nin bir Senelik Zirai Ürün Miktarl ve Hasatlar Toplamı: ${ }^{62}$

\begin{tabular}{|l|r|r|r|r|r|r|}
\hline \multirow{2}{*}{$\begin{array}{l}\text { Kazaların } \\
\text { İsimleri }\end{array}$} & \multicolumn{7}{|c|}{ Zirai Ürünler Miktarl } \\
\cline { 2 - 7 } & Buğday & \multicolumn{1}{c|}{ Arpa } & \multicolumn{1}{c|}{ Misır } & \multicolumn{1}{c|}{ Patates } & \multicolumn{1}{c|}{ Kenevir } & \multicolumn{1}{c|}{ Tütün } \\
\cline { 2 - 7 } & Dönüm & Dönüm & Dönüm & \multicolumn{1}{c|}{ Dönüm } & \multicolumn{1}{c|}{ Dönüm } & Dönüm \\
\hline Rize & 1.000 & 5.000 & 87.091 & 4.141 & 1.400 & - \\
\hline Atina & 1.000 & 2.000 & 3.000 & 600 & 1.300 & 359 \\
\hline Hopa & - & - & 33.844 & - & - & - \\
\hline Toplam & 2.000 & 7.000 & 123.935 & 4.741 & 2.700 & 359 \\
\hline
\end{tabular}

57 Türkiye Cumhuriyeti Devlet Salnamesi 1926-27, s.881.

58 Türkiye Cumhuriyeti Devlet Salnamesi 1926-27, s.882.

59 Türkiye Cumhuriyeti Devlet Salnamesi 1926-27, s.882-883.

60 Türkiye Cumhuriyeti Devlet Salnamesi 1926-27, s.882-883.

61 Türkiye Cumhuriyeti Devlet Salnamesi 1927-28, s.902.

62 Türkiye Cumhuriyeti Devlet Salnamesi 1927-28, s.903. 


\begin{tabular}{|c|c|c|c|c|c|c|}
\hline \multirow[t]{2}{*}{$\begin{array}{l}\text { Kazaların } \\
\text { İsimleri }\end{array}$} & $\ddot{U} z \ddot{u} m$ Băg $l$ & 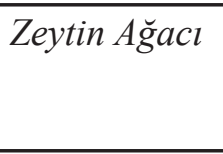 & $\dot{\text { Incir Ăgacl }}$ & $\begin{array}{c}\text { Limon, } \\
\text { Portakal, } \\
\text { Mandalina }\end{array}$ & Fasulye & Pirinç \\
\hline & Dönüm & Sak & Sak & Adet & Dönüm & Dönüm \\
\hline Rize & 400 & 400 & 4.050 & 60.740 & 1.500 & 46 \\
\hline Atina & 2.000 & - & 5.000 & 2.000 .000 & 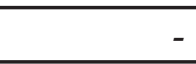 & - \\
\hline Hopa & - & - & - & - & 1.500 & 825 \\
\hline Toplam & 2.400 & 400 & 9.050 & 2.060 .740 & 3.000 & 871 \\
\hline
\end{tabular}

1927-28-Rize Vilayeti Zirai Üretim miktarl. ${ }^{63}$

\begin{tabular}{|c|c|c|c|c|c|c|}
\hline \multirow{3}{*}{$\begin{array}{l}\text { Kazalarin } \\
\text { Isimleri }\end{array}$} & \multicolumn{6}{|c|}{ Üretim Miktarl } \\
\hline & Buğday & Arpa & Mistr & Patates & Kenevir & Tütün \\
\hline & Kilo & Kilo & Kilo & Kilo & Kilo & Kilo \\
\hline Rize & 150.000 & 750.000 & 15.850 .562 & 838.200 & 51.000 & - \\
\hline Atina & 100.000 & 200.000 & 5.100 .000 & 60.000 & 15.000 & 2.988 \\
\hline Hopa & - & - & 2.791 .600 & - & - & - \\
\hline Toplam & 250.000 & 950.000 & 23.742 .162 & 898.200 & 66.000 & 2.988 \\
\hline \multirow[t]{2}{*}{$\begin{array}{l}\text { Kazalarin } \\
\text { İsimleri }\end{array}$} & $\begin{array}{l}\ddot{U} z \ddot{u} m \\
\text { Asma }\end{array}$ & Zeytin & Incir & $\begin{array}{c}\text { Limon, } \\
\text { Portakal, } \\
\text { Mandalina }\end{array}$ & Fasulye & Pirinç \\
\hline & Kilo & Kilo & Kilo & Adet & Kilo & Kilo \\
\hline Rize & 800.000 & 12.000 & 200.000 & 35.000 .000 & 108.000 & 2.300 \\
\hline Atina & 125.000 & - & 50.000 & 2.000 .000 & - & - \\
\hline Hopa & - & - & - & - & 35.000 & 41.000 \\
\hline Toplam & 925.000 & 12.000 & 250.000 & 37.000 .000 & 143.000 & 43.300 \\
\hline
\end{tabular}

1927-28 devlet salnamesine göre Vilayette bulunan büyük ve küçükbaş hayvanlar ve bunlardan elde edilen hayvansal ürünlerin miktarları da aşağıdaki tablolarda gösterilmiştir.

1927-28-Rize Vilayeti Hayvan Miktart: ${ }^{64}$

\begin{tabular}{|c|c|c|c|c|c|c|c|c|c|}
\hline \multirow{3}{*}{$\begin{array}{l}\text { Kazaların } \\
\text { İsimleri }\end{array}$} & \multicolumn{9}{|c|}{ Hayvanat-l Ehliye } \\
\hline & Barkir & Kisrak & Merkep & Katır & Inek & Öküz & Manda & Koyun & Keçi \\
\hline & $B a s ̧$ & Baş & Baş & Baş & Baş & Baş & Baş & Baş & Baş \\
\hline Rize & 304 & 210 & 47 & 338 & 23.840 & 2212 & 9 & 10206 & 7773 \\
\hline Atina & 60 & 65 & 3 & 128 & 6677 & 1019 & 14 & 6252 & 4647 \\
\hline Hopa & 224 & 224 & 3 & 20 & 7745 & 909 & 10 & 9149 & 13.663 \\
\hline Toplam & 588 & 499 & 53 & 596 & 38262 & 4140 & 33 & 25.607 & 26.089 \\
\hline
\end{tabular}

63 Türkiye Cumhuriyeti Devlet Salnamesi 1927-28, s.903.

64 Türkiye Cumhuriyeti Devlet Salnamesi 1927-28, s.904. 
1927-28-Rize Vilayeti Hayvansal ürünler: ${ }^{65}$

\begin{tabular}{|l|l|l|l|}
\hline \multicolumn{4}{|c|}{ Hayvansal Ürünler } \\
\hline $\begin{array}{l}\text { Ka za la rın } \\
\text { İsimleri }\end{array}$ & Süt & Yün Yapă̆ & Keçi Kılı \\
\cline { 2 - 4 } & Kilo & Kilo & Kilo \\
\hline Rize & - & - & - \\
\hline Atina & 40.000 & 5.000 & 2.000 \\
\hline Hopa & - & - & - \\
\hline Toplam & 40.000 & 5.000 & 2.000 \\
\hline
\end{tabular}

1927-28 yllında Rize vilayetinin genel gelirleri 320 bin 224 lira, özel gelirleri 414 bin 965 lira olup, belediyenin geliri 32 bin 817 , Mapavri nahiyesi belediyesinin 3000, Hopa kasabası belediyesinin 9876, Arhavi kazası belediyesinin 1091 ve Viçe nahiyesi belediyesinin 2347 ve Atina kazası belediyesinin 4273 ve Ardeş nahiyesi belediyesinin 700 liradir. ${ }^{66}$

1928-29 Devlet salnamesine göre Rize vilayetindeki ziraat ve hayvancılık durumu aşağıdaki tabloda gösterilmiş̧ir.

1928-29-Rize Vilayeti Zirai Ürünler miktarl: ${ }^{67}$

\begin{tabular}{|c|c|c|c|c|c|c|c|c|c|}
\hline \multirow[t]{2}{*}{ Kazalar } & Arpa & Patates & Pirinç & Mistr & Kenevir & $\begin{array}{l}\ddot{U} z \ddot{u} m \\
B a \breve{g}_{l}\end{array}$ & $\begin{array}{l}\dot{I} n c i r \\
\mathrm{Ağacl}\end{array}$ & $\begin{array}{l}\text { L i m o } n, \\
\text { Portakal }\end{array}$ & Fasulye \\
\hline & Dönüm & Dönüm & Dönüm & Dönüm & Dönüm & Dönüm & Sak & Sak & Dönüm \\
\hline Rize & 4.500 & 4.150 & 50 & 88.000 & 1.600 & 2.500 & 5.850 & 60.740 & 16.000 \\
\hline Atina & 200 & 1.600 & 5.000 & 25.550 & 1.300 & 2.500 & 5.000 & 15.185 & 12.000 \\
\hline Hopa & 500 & 125 & 2.000 & 15.000 & 900 & 1.800 & 4.800 & 12.417 & 9.000 \\
\hline Toplam & 5.200 & 5.875 & 7.050 & 128.550 & 3.800 & 6.300 & 15.650 & 88.342 & 37.000 \\
\hline
\end{tabular}

1928-29-Rize Vilayeti Hayvan miktart: ${ }^{68}$

\begin{tabular}{|c|c|c|c|c|c|c|c|c|}
\hline & Öküz & Manda & $A t$ & Kisrak & Kattr & Eşek & Koyun & Keçi \\
\hline Kazalar & Baş & Baş & $B a s ̧$ & Baş & Baş & $B a s ̧$ & Baş & $B a s ̧$ \\
\hline Rize & 1.894 & 8 & 458 & 56 & 432 & 49 & 9.693 & 6.195 \\
\hline Atina & 1.005 & 12 & 76 & 41 & 42 & 6 & 6.209 & 3.956 \\
\hline Hopa & 844 & 5 & 276 & 37 & 35 & 6 & 6.604 & 11.994 \\
\hline Toplam & 3.743 & 25 & 810 & 234 & 509 & 61 & 22.506 & 22.145 \\
\hline
\end{tabular}

65 Türkiye Cumhuriyeti Devlet Salnamesi 1927-28, s.904.

66 Türkiye Cumhuriyeti Devlet Salnamesi 1927-28, s.908.

67 Türkiye Cumhuriyeti Devlet Yıllığ1 1928-29, s.510.

68 Türkiye Cumhuriyeti Devlet Yıllığ1 1928-29, s.512. 
1928-29- Rize Vilayeti Hayvansal Ürünler: ${ }^{69}$

\begin{tabular}{|c|c|c|c|}
\hline & Süt & Yün Yapăğ & Keçi kll \\
\hline Kazalar & Kilo & Kilo & Kilo \\
\hline Rize & 240.000 & 5.000 & 3.000 \\
\hline Atina & 10.000 & 4.000 & 2.000 \\
\hline Нора & 75.000 & 3.500 & 6.000 \\
\hline Toplam & 325.000 & 12.500 & 11.000 \\
\hline
\end{tabular}

1928-29 devlet salnamesine göre Rize vilayetinin genel geliri 32 bin 800 lira, özel geliri 517 bin 534 lira, belediye geliri ise 41 bin liradır. Atina kazası belediyesinin 5 bin 691, Hopa kazası belediyesinin ise 8 bin 500 lira geliri bulunmaktadır. ${ }^{70}$

Yukarıda verilen doğrultusunda bir değerlendirme yapıldığında, en fazla üretilen ziraai ürünün mısır, portakal ve fasulye olduğu görülmektedir. Ayrıca 1927-28 yılı devlet salnamesine göre 1372 kilometre kare arazinin ziraate uygun, 3033 kilometre karesinin ise ziraate uygun olmadığ 1 bilgisi ile elde bulunan 1941 yılına ait veriler ${ }^{71}$ karşılaş̧tırıldığında ziraate elverişli alanların yıllar içinde sayısının arttığı ve aynı şekilde elverişsiz alanların da azaldığı anlaşılmaktadır. Hayvancılık konusunda ise, Rize vilayetinin önemli geçim kaynaklarından birini hayvancılığın oluşturduğu bilinmekle birlikte coğrafi yapı, engebeli arazi, ağaçlarla kaplı olması gibi nedenlerle sürü hayvancılı̆̆ının yapılamadığ 1 bilgisi ${ }^{72}$ ile devlet salnamelerinde yer alan veriler örtüssmektedir. Salnamelerde yer alan bilgiler doğrultusunda Karadeniz bölgesinde yer alan diğer illerle ilgili yapılan çalışmalarda ${ }^{73}$ Rize'deki hayvansal üretim miktarları ile örneğin Sinop ilinin ${ }^{74}$ üretim miktarları karşılaştırıldığında Rize'deki süt, yün yapağı ve keçi kılı miktarlarının oldukça düşük olduğu gözlemlenmektedir. Bunun da ilin coğrafi durumunun hayvancilığa fazla elverişli olmamasından kaynaklandığını söylemek yanlış olmayacaktır. Sinop ilinde üretim mitarları milyonlu rakamlara ulaşırken örneğin Atina kazasında ancak 40 bin kilo süt üretimi yapılabilmektedir. Ancak bunun yanında yün yapağı miktarı bakımından Sinop ili Ayancık kazasıyla Rize ili Atina kazası karşılaştırıldığında Atina kazasındaki üretimin 3’te 2 oranında daha fazla olduğu anlaşılmaktadır. Ayrıca Sinop ili merkez kazasında inek ve keçi miktarlarının Rize ili merkez kazasından daha az olduğu dikkat çekmektedir. İnek sayısının azlığına ragmen Sinop ilinde süt üretimi daha fazladır. Keçi sayısının ise Rize merkez kazasında daha fazla olması, Rize'de büyük baş hayvancılıktan ziyade küçük baş hayvancılığın yaygınlığını kanıtlar niteliktedir. Ayrıca yukarıda belirtildiği üzere büyükbaş hayvanların sütünden ziyade gübresi için beslendiği bilgisini de teyit etmektedir. Diğer

69 Türkiye Cumhuriyeti Devlet Y1llı̆̆ 1928-29, s.512.

70 Türkiye Cumhuriyeti Devlet Y1llı̆̆1 1928-29, s.515.

711941 yılında Rize vilayetinde ziraate elverişli arazinin 95.000 hektar olduğu, 89.500 hektarın ise elverişsiz olduğu bilinmektedir. Bu veriler için bkz. Songül Alşan, "Rize'de Ziraat, Balıkçılık ve Hayvancılık", s.194.

72 Cumhuriyetin 50. Yılında Rize, 1973 İl Yıllığı, Tisa Matbaası, Ankara, 1973, s. 160.

73 Örnek olarak bkz. Hadiye Y1lmaz, "Türkiye Cumhuriyeti Devlet Salnamesi 1925-26'da Giresun Vilayeti”, Karadeniz Sosyal Bilimler Dergisi, Cilt:8, Say1:15, 2016, s.33-53.; Hürü Sağlam Tekir, "19271928 Devlet Salnamesinde Sinop Vilayeti", Kafkas Üniversitesi Sosyal Bilimler Enstitüsü Dergisi, Sayı:13, 2014, Kars, s.133-145.; Bir başka çalışma için bkz. Hadiye Yılmaz, "Türkiye Cumhuriyeti Devlet Salnamelerinde Ordu Vilayeti”, Karadeniz, Sayı:31, 2016, s.118-138.

74 Hürü Sağlam Tekir, “1927-1928 Devlet Salnamesinde Sinop Vilayeti, s.139. 
yandan belediye gelirleri ile ilgili olarak başka illerle ilgili yapılan çalışmalardaki ${ }^{75}$ bilgilerle karş1laştırıldığında, örneğin Afyon ilinin merkez belediye geliri 1926-27'de 67 bin lira iken, Rize merkez belediyesinin geliri 1928-29' da 41 bin liradır. ${ }^{76}$ Yine bir başka çalışmaya göre, Van vilayeti merkez kazasının 1926-27 devlet salnamesine göre bir yıllık geliri 88 bin 521 lira iken, Rize vilayeti merkez kazasının geliri 32 bin 800 liradır. ${ }^{77}$ İncelediğimiz salnamelerde verilen bilgiler 1şı̆̆ında Rize vilayetinin genel gelirlerinin 1925'ten 1929'a gelindiğinde 3 'te 1 oranında azaldığ 1 anlaşılmaktadır.

\section{Rize Vilayetinin Eğitim-Kültür-Sağlık Durumu}

Rize vilayetinde okul sayılarına bakıldığında merkez kazasında 1925-26 yıllarında 1 orta, 1 imam hatip, altı aylık kız, 65 ilk erkek okulu ve bunların 4330 devam eden öğrencisi, Atina kazasında 1 ilk kız, 17 ilk erkek okulu olup, 1166 devam eden öğrencisi ve Hopa kazasında 4 ilk kız ve 26 ilk erkek okulu ve 2500 devam eden öğrencisinin mevcut olduğu görülmektedir. ${ }^{78}$ 1926-27 devlet salnamesine göre Rize vilayetinde 2 kız, 62 erkek okulu olup, bunlara devam eden 132 kız ve 2881 erkek öğrenci; Atina kazasında 2 kız ve 29 erkek okulu olup 37 kız ve 1285 erkek öğrenci ve Hopa kasasında 4 kız ve 26 erkek okulu ve $21 \mathrm{kız} 1379$ erkek öğrencisi vardır. Merkez kaza ile diğer iki kazada toplam 8 kız ve 117 erkek okulu ve bu okullarda 179 kız ve 5545 erkek öğrenci bulunmaktadır. ${ }^{79} 1927-28$ yıl1 verilerine göre ise, Rize'de 63 öğrencili bir erkek orta okuluyla 3608 öğrencili muhtelif, 53 ilk erkek ve kız okulu vardır ve bundan başka vilayette 3704 öğrencili 55 ilk erkek ve kız okulu vardır. ${ }^{80}$ 1928-29 devlet salnamesinde vilayetin okul durumuna dair herhangi bir veri bulunmamaktadir.

Vilayette bulunan cemiyetler de devlet salnamelerinde belirtilmiştir. 1925-29 yılları arasında mevcut cemiyetlerin Hilal-i Ahmer, Cumhuriyet Halk Fırkası, Türk Ocağı, Ticaret ve Sanayii, Ziraat Odaları, Teyyare, Himaye-i Etfal, Muallimler Birliği, Kayıkçılar cemiyeti olduğu görülmektedir. ${ }^{81}$ Ayrıca vilayette 1926'da yayınlanmaya başlanan Yeni Ay mecmuasından bahsedilmektedir. İlmi, edebi bir dergi olan bu mecmuanın imtiyaz sahibi ve sorumlu müdürü Hüseyin Avni Bey'dir. ${ }^{82}$

75 Zeynel Özlü, “Cumhuriyetin İlk Yıllarında Bolvadin Kazasına Dair Bulgular”, Bolvadin Araştırmaları, Eğitim Yayınevi, Konya, 2018, s.2470-2498.; Güneş Şahin, "1926-27 ve 1928 Türkiye Cumhuriyeti Devlet Salnamelerinde Van Vilayeti”, Turkish Studies, Volume:10/9, 2015, s.429-444.; Bir başka çalışma için bkz. Metin Kopar, "Türkiye Cumhuriyeti Devlet Salnamelerinde Adiyaman (1925-1930)", Sosyal Bilimler Dergisi, Cilt:7, Say1:13, 2017, s.180-196.

76 Zeynel Özlü, “Cumhuriyetin İlk Yıllarında Bolvadin Kazasına Dair Bulgular”, s.2482.

77 Güneş Şahin, “1926-27 ve 1928 Türkiye Cumhuriyeti Devlet Salnamelerinde Van Vilayeti”, s.434.

78 Türkiye Cumhuriyeti Devlet Salnamesi 1925-26, s.631.

79 Türkiye Cumhuriyeti Devlet Salnamesi 1926-27, s.878.

80 Türkiye Cumhuriyeti Devlet Salnamesi 1927-28, s.909.

81 Türkiye Cumhuriyeti Devlet Salnamesi 1925-26, s.631; Türkiye Cumhuriyeti Devlet Salnamesi 192627, s.878; Türkiye Cumhuriyeti Devlet Salnamesi 1927-28, s.909.; Rize vilayetindeki cemiyetlerle ilgili ayrıntılar için bkz. İsmail Özdoğan, Rize Sosyal, Siyasal ve Ekonomik Yapısı, s.107-120.

82 Türkiye Cumhuriyeti Devlet Salnamesi 1927-28, s.909.; Yeni Ay dergisi, ilk sayısı Kasım 1926 'da 16 sayfa olarak yapılmış; Şubat 1927'de 40 sayfa olarak son sayısı yayınlanmıştır. Bkz. İsmail Özdoğan, Rize Sosyal, Siyasal ve Ekonomik Yapısı, s.122. 
Vilayetin sağlık durumuyla ilgili olarak ise, 1926-27 devlet salnamesinde ilin sihhi durumunun iyi olduğu bilgisine yer verilmektedir. Merkezde 40 yataklı bir hastane inşa edildiği bundan başka Rize ve Hopa'da 10'ar yataklı birer muayene ve tedavi evi bulunduğu ve Atina kazasının Hemşin nahiyesinde iptidai şekilde bir kaplıca bulunduğu ifade edilmektedir. ${ }^{83} \mathrm{Bu}$ kaplıcaların şifası henüz anlaşılamamış ise de 40 santigrat derece sıcaklıkta bulunan Arder suyunun demir kükürtlü olmasından dolayı romatizma ve egzema gibi hastalıklar üzerindeki etkisi tecrübeyle anlaşılmıştır. Ancak kaplıca henüz modern bir durumda olmamasına rağmen her sene temmuzdan ağustos sonuna kadar ziyaretçi sayısının 15 -20 bine çıktığ 1 görülmektedi ${ }^{84} 1927-28$ devlet salnamesine göre ise, vilayetin sihhi durumunun iyi olduğu ancak ara sira tifo ve dizanteri vakalarına ve k1zıl, kızamık, kabakulak ve boğmaca öksürüğüne sık sık; ayrıca verem gibi frenginin de çeşitli şekillerine de rastlanmaktadır. Salnameye göre Rize'de bir hastane yoktur; yalnız merkez vilayette 10 ve Hopa'da 5 yatakl1 2 muayene ve tedavi evi vardır, bunlardan başka sıhhi bir müessese olmadığı ve il dahilinde Atina kazası Hemşin mevkiinde kükürtlü bir 1lıca olduğu belirtilmektedir. ${ }^{85} 1940$ 'lara gelindiğinde ancak vilayette 40 yataklı bir memleket hastanesinin açılmış olduğu görülmektedir. ${ }^{86}$

\section{Rize Vilayetinin Maden, Orman, Fabrika ve Yol Durumu}

1926'da merkez kazada sadece bir manganez madeni olduğu anlaşılmaktadır. ${ }^{87}$ Atina kazasının hemen her yönünde keşfedilmiş simli kurşun, bakır, manganez, çinko, kalay, demir, kükürt madenleri olup, bazıları ruhsatname aldıysa da henüz hiç birisi işletilememiştir. ${ }^{88}$ Hopa kazasında demir, bakır, manganez vardır ancak işletilen maden yoktur. Hopa'nın batisında 1 saat mesafede iskele bulunan Pervenit (Pirunit) karyesinde manganez varsa da bu madenin işletme imtiyazı verilmemiş ve henüz hiç bir şirket tarafından işletilmemiştir. Arhavi civarında şahsa ait ecnebi şirketlerle işletilmek üzere bir mukavele imzalanmış ancak henüz işe başlanmamıştır. Ayrıca Caibet karyesinde demir madeni keşfedilmiştir. ${ }^{89}$ Rize vilayetinin Emineddin mahallesi merkezde Arif Paşa ve Şürekasına ait işletilmeyen dört adet manganez madeni ile Atina kazasının Ardeş mevkiinde simlikurşun ve bakır, çinko, kalay, demir, kükürt, manganez madenleri vardır. ${ }^{90}$

86 Orhan Naci Ak, Rize Tarihi, Trabzon, Rize Halk Eğitim Merkezi Yayını, 2000, s.219.; Ayrıca vilayetin sağlık durumu bölgede görülen salgın hastalıklarla ilgili ayrıntılar için bkz. Elif Yormaz, Rize Gazetesine Göre Rize'de Sosyo-Ekobomik ve Kültürẹl Hayat, s.20-22.; Fevzi Çakmak, "Sağlık ve Sosyal yardımlaşma", Cumhuriyet Döneminde Rize I, RTEÜ Yayını, 2018, s.124-138. 
1927-28-Rize Vilayetindeki Madenler: ${ }^{91}$

\begin{tabular}{|c|c|c|c|c|c|c|c|}
\hline \multirow{2}{*}{$\begin{array}{l}\text { Kazaların } \\
\text { Isimleri }\end{array}$} & \multicolumn{2}{|c|}{ Keşfedilmiş Madenler } & \multicolumn{5}{|c|}{ Kaza dahilinde bulunan Fermanlı Madenler } \\
\hline & Mevkii & Cinsi & Mevkii & Cinsi & Sahibinin Adl & Imtiyaz Tarihi & Cins \\
\hline Rize & - & Manganez & $\begin{array}{l}\text { Emineddin } \\
\text { Mah. }\end{array}$ & Manganez & $\begin{array}{l}\text { Arif Paşa ve } \\
\text { Şürekası }\end{array}$ & 6.10 .341 & Manganez \\
\hline // & - & - & /I & $/ /$ & $/ /$ & 6.10 .341 & // \\
\hline // & - & - & // & $/ /$ & $/ /$ & 6.10 .341 & // \\
\hline // & - & - & // & $/ /$ & $/ /$ & 6.10 .341 & // \\
\hline // & - & - & $\begin{array}{l}\text { Hanis Kamnit } \\
\text { Mah. }\end{array}$ & $/ /$ & $\begin{array}{l}M e h m e t \\
\text { Münim Efendi }\end{array}$ & $\begin{array}{l}\text { 23.Kanипи } \\
\text { Evvel Sene } \\
1926\end{array}$ & // \\
\hline Atina & Ardeş & Simli Kurşun & - & - & - & - & - \\
\hline // & $/ /$ & Bakır & - & - & - & - & - \\
\hline // & Atina & Manganez & - & - & - & - & - \\
\hline // & Ardeş & Çinko & - & - & - & - & - \\
\hline // & $/ /$ & Kalay & - & - & - & - & - \\
\hline // & // & Demir & - & - & - & - & - \\
\hline$/ /$ & $/ /$ & Kükürt & - & - & - & - & - \\
\hline
\end{tabular}

Rize vilayetinin orman durumuna ilişkin olarak ise salnamelerde bilgiler mevcuttur. Bunlara göre, Rize'de miri ormanlar iskele ve sahile azami yirmi asgari on iki saat uzaklıkta olup ekseriyetle ladin ve köknar ağaçlarını içerir. Kayın ağaçları yüzde 5 oranındadır. $\mathrm{Bu}$ ağaçları içeren ormanlar Kura-yı Seba nahiyesi mıntıkası dahilinde olup, 2800 hektar civarındadır; ayn mıntıkada bin hektarlık kayın ormanları vardır. ${ }^{92}$ Atina kazasında her karyede halka ait ormanlıklar ve baltalıklar müstesna olmak üzere hükümete ait çeşitli mevkilerde çam, gürgen, kestane, şimşir, meşe, karaağaç, kızılağaç gibi henüz balta girmemiş ormanlıklar bulunmaktadır. ${ }^{93}$ Hopa kazasında ise ormanlar işletilememiş ve içlerinde gezilemeyecek bir duruma gelmişlerdir. Yolların olmaması gibi nedenlerle bu milli servetten yararlanılamamaktadır. Araba ve hayvan işlemediği için kesilen ağaçlar omuzlarda veya derelerin akıntısına birakılarak nakil olunur. Kazanın toplam ormanları 77 bin 349 hektardır. Kazanın güneyinde Artvin Borçka nahiyesi sınırına 4-5 saat mesafede 5512 hektarlık Sultan Selim ormanı vardır ve bu ormanda \%65 oranında istifade edilen gürgen, $\% 10$ nispetinde kızılağaç , $\% 5$ oranında ıhlamur, $\% 20$ oranında karaağaç ve diğer ağaçlar bulunur. ${ }^{94}$ Merkez kazanın 4 saat güneybatısında Murgul kazasıyla sınır Dahastı adıyla bilinen orman 14 bin 700 hektardır ve \%70 gürgen, \%10 kızılağaç, \%13 çam ve ıhlamur, \%5 diğer ağaçlar vardır. Merkez kazanın güneybatısında 5 saat uzaklıkta 4900 hektar Atina ve Yusufeli kazalarına sinır olan Balıklı adıyla bilinen orman mevcuttur ve bu ormanda $\% 80$ oranında gürgen, ve $\% 20$ oranında kızılağaç, çam ve ihlamur vardır. Mevcut ormanın iskelesini oluşturan Viçe ve Arhavi nahiyelerine mesafesi 5-6 saattir. ${ }^{95}$

\footnotetext{
91 Türkiye Cumhuriyeti Devlet Salnamesi 1927-28, s.906.

92 Türkiye Cumhuriyeti Devlet Salnamesi 1926-27, s.879.

93 Türkiye Cumhuriyeti Devlet Salnamesi 1926-27, s.879.

94 Türkiye Cumhuriyeti Devlet Salnamesi 1926-27, s.880.

95 Türkiye Cumhuriyeti Devlet Salnamesi 1926-27, s.881.
} 
Rize vilayetinin 1927-28 ve 1928-29 y1larına ait orman durumuna ait ayrıntılar aşağıdaki tablolarda gösterilmiştir.

1927-28 Rize Vilayetindeki Ormanlar: ${ }^{96}$

\begin{tabular}{|c|c|c|c|c|c|c|c|c|c|c|c|c|}
\hline \multirow{3}{*}{$\begin{array}{l}\text { Kazaların } \\
\text { Isimleri }\end{array}$} & \multirow{2}{*}{$\begin{array}{l}\text { Ormanların } \\
\text { Yüzölçümü }\end{array}$} & \multicolumn{11}{|c|}{ Ormanlardaki Ăgaç Çeşitleri } \\
\hline & & Karaçam & Akçam & Meşe & Kestane & Çalılık & Köknar & Ladin & Kayın & Konil & Şimşir & Ihlamur \\
\hline & Hektar & Hektar & Hektar & Hektar & Hektar & Hektar & Hektar & Hektar & Hektar & Hektar & Hektar & Hektar \\
\hline Rize & 57.800 & - & - & 1.500 & 2.000 & - & 2.950 & 19.000 & 3.000 & 1.500 & 1.300 & - \\
\hline Atina & 3.780 & - & 1 & - & 1 & 500 & - & - & - & - & - & - \\
\hline Hopa & 77.349 & 12.314 & 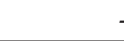 & - & 18.057 & 6.047 & - & - & 39.790 & - & - & 1.136 \\
\hline Toplam & 138.929 & 12.314 & 1 & 1.500 & 20.058 & 6.547 & 2.950 & 19.000 & 42.790 & 1.500 & 1.300 & 1.136 \\
\hline
\end{tabular}

1927-28-Rize Vilayetinde Bir Senelik Kereste ve Mahrukat: ${ }^{97}$

\begin{tabular}{|l|r|r|r|}
\hline \multirow{4}{*}{$\begin{array}{l}\text { Ka a a l a r ın } \\
\text { İsimleri }\end{array}$} & \multicolumn{3}{|c|}{ Ormanlarda Bir Sene İçinde Kesilen Kereste ve } \\
\cline { 2 - 4 } & Kereste & \multicolumn{1}{|c|}{ Odun } & \multicolumn{1}{c|}{ Kömürr } \\
\cline { 2 - 4 } & Metreküp & Kantar & \multicolumn{1}{|c|}{ Kantar } \\
\hline Rize & 15.650 & 20.000 & - \\
\hline Atina & 376 & 19.390 & 75 \\
\hline Hopa & - & & - \\
\hline Toplam & 16.026 & 39.390 & 75 \\
\hline
\end{tabular}

1928-29-Rize Vilayetindeki Ormanlar: ${ }^{98}$

\begin{tabular}{|c|c|c|c|c|c|c|c|c|c|c|c|c|}
\hline \multirow[b]{2}{*}{ Kazalar } & \multirow{2}{*}{$\begin{array}{l}\text { Ormanların } \\
\text { Yüzölçümü }\end{array}$} & \multicolumn{11}{|c|}{ Ormanlardaki Ağaç Çeşitleri } \\
\hline & & Akçam & Kızılçam & Meşe & Kestane & Köknar & Ladin & Kayın & Çalılık & Konil & Şimşir & Ihlamur \\
\hline Rize & 57.800 & - & - & 1.500 & 2.000 & 2.950 & 19.000 & 3.000 & & 1.500 & 1.300 & - \\
\hline Atina & 3.780 & 1 & - & - & 1 & - & - & - & 500 & - & - & - \\
\hline
\end{tabular}

1928-29-Rize Vilayetindeki Orman Ürünleri: ${ }^{99}$

\begin{tabular}{|l|r|r|r|}
\hline \multirow{2}{*}{ Kazalar } & \multicolumn{3}{|c|}{ Bir Senede Kesilen } \\
\cline { 2 - 4 } & \multicolumn{1}{|c|}{ Kereste } & \multicolumn{1}{c|}{ Odun } & \multicolumn{1}{c|}{ Kömür } \\
\cline { 2 - 4 } & Metreküp & Kantar & \multicolumn{1}{|c|}{ Kantar } \\
\hline Rize & 15.420 & 18.800 & 0 \\
\hline Atina & 376 & 19.390 & 75 \\
\hline Hopa & 0 & 0 & 0 \\
\hline Toplam & 15.796 & 37.190 & 75 \\
\hline
\end{tabular}

96 Türkiye Cumhuriyeti Devlet Salnamesi 1927-28, s.905.

97 Türkiye Cumhuriyeti Devlet Salnamesi 1927-28, s.905.

98 Türkiye Cumhuriyeti Devlet Yıllığ1 1928-29, s.514.

99 Türkiye Cumhuriyeti Devlet Yıllığı 1928-29, s.514. 
1925-29 Devlet salnamelerinde vilayette bulunan şirket, fabrika ve bankalara dair de bilgiler verilmektedir. Bu bilgilere göre, 1925 yılında Rize vilayetinde herhangi bir şirket ve fabrika yoktur. ${ }^{100}$ Atina kazasında demircilik, marangozluk, taşçılık, furıncılık, peynircilik, gemicilik, kerestecilik, kunduracılık, terzilik, kalafatc1lık ve dokumacılık gibi erbabı sanayi varsa da bunların çoğu iptidai haldedir. Herhangi bir sanayiye ait bir makina olmadığı gibi fabrika da yoktur. Ancak iptidai bir şekilde el tezgahlarında pamuk ve yün ile çeşitli yatak çarşafları, keten sofra örtüleri, peçete ve gömlekler ve ayrıca yünden elbiselik kumaş imal edilmektedir. Kazada banka ve şirket olmayıp yalnız 13 bin 500 lira sermayeli bir ziraat bankası şubesi vardır. ${ }^{101}$ Rize'de Ziraat Bankasının bir şubesi vardır ve sermayesi 34.000 Türk lirasıdır. İlin Atina kazasında Ziraat Bankasının 1300 lira sermayeli bir sandığı vardır. ${ }^{102}$ Rize Kalapotamos'ta Abidero kereste fabrikası ve Rize merkezde peştemal üretimi yapan bir tezgah vardır. ${ }^{103}$ Kereste fabrikası ile ilgili olarak 1926 senesinde bu fabrikanın Sadıkoğlu Ruşen beye ait olduğu ve yörede yetmiş kişiye iş imkanı sağladığı belirtilmekteydi. ${ }^{104}$

1927 sanayii sayımı sonuçlarına göre, Rize merkezinde sanayii kolları olarak tarım, hayvancılık, av ve balıkçılık, bitkisel maddeler ve ağaç ürünleri işleme, inşaat ve madencilik dikkati çekmekteydi. Toplam 397 işletmenin olduğu ve 840 kişinin bu işletmelerde istihdam edildiği anlaşılmaktadır. ${ }^{105}$ Rize'deki el tezgahlarıyla yapılan dokumacılığın büyük kısmı kendir dokumacılığı ve keten bezi yapımına dayanmaktaydı. Rize'nin nemli ikliminin elvermesi sayesinde oldukça ince kendir ipleri üretiliyordu. ${ }^{106}$ Bu şekilde hazırlanan kendir iplerinden bölgede "Feretiko" adı verilen bezler dokunuyor ve bunlardan içlik, gömlek, vb. giyim eşyaları üretiliyordu. ${ }^{107}$

Rize vilayetinin yol durumuna dair bilgilere bakıldığında 1927-28 ve 192829 yıllarına ait salnamelerde ilin karayollarına ait uzunluk, sağlamlık, tamirat bilgileri verilmektedir. Aşağıdaki tablolarda ilin yol durumuna ait ayrıntılar bulunmaktadır.

100 Türkiye Cumhuriyeti Devlet Salnamesi 1925-26, s.631.

101 Türkiye Cumhuriyeti Devlet Salnamesi 1926-27, s.879.

102 Türkiye Cumhuriyeti Devlet Salnamesi 1927-28, s.906.

103 Türkiye Cumhuriyeti Devlet Salnamesi 1927-28, s.906.

104 İsmail Özdoğan, Rize Sosyal, Siyasal ve Ekonomik Yapısı, s.162.

105 Sanayi Sayımı 1927, Devlet İstatistik Enstitüsü, Ankara, 1969. s.39.; Ayrıca Rize'de sanayiinin gelişimi hakkındaki ayrıntılar için bkz. Ahmet Çavuş, Rize İlinde Sanayii, Pegem Yayıncılık, Ankara, 2016.

106 "Rize", Yurt Ansiklopedisi, s.6386.

107 Arer, Rahmi; Türkiyede Çaycılık ve Turistik Sosyal Kültürel Rize, İstanbul,1969, s.247. 
1927-28 Rize Vilayetinde Yollar:108

\begin{tabular}{|c|c|c|c|c|c|}
\hline \multirow{4}{*}{ Yolun Başlangıcl--Sonu } & \multicolumn{5}{|c|}{ Şoseler } \\
\hline & \multirow{2}{*}{$\begin{array}{c}\text { Yolun } \\
\text { Uzunluğu }\end{array}$} & \multirow{2}{*}{$\begin{array}{c}\text { Săglam } \\
\text { Kısmı }\end{array}$} & \multicolumn{2}{|c|}{ Tamire Muhtaç Kısmı } & \multirow{2}{*}{$\begin{array}{c}\text { Yeni İnşa } \\
\text { Olunmakta }\end{array}$} \\
\hline & & & $\begin{array}{c}\text { Tamir } \\
\text { Olunmakta }\end{array}$ & $\begin{array}{c}\text { Tamire } \\
\text { Başlanmamış }\end{array}$ & \\
\hline & $K m$ & $K m$ & $K m$ & $K m$ & $K m$ \\
\hline $\begin{array}{l}\text { Rize-Of hududunu ayıran Kalapotamos } \\
\text { deresi sonu-Rize'nin Viçe kazasına } \\
\text { mülhak Batum hududunu ayıran Sarp } \\
\text { mevkii }\end{array}$ & $178+000$ & $75+000$ & $75+000$ & $103+000$ & - \\
\hline $\begin{array}{l}\text { Hopa Kasabası-Artvin vilayetine mülhak } \\
\text { Borçka Kazası hududu }\end{array}$ & $12+750$ & - & - & - & $12+750$ \\
\hline $\begin{array}{l}\text { Arhavi Nahiye merkezi-Potohor (Potur) } \\
\text { Karyesi Yusufeli Hududu }\end{array}$ & $25+000$ & - & - & - & $10+000$ \\
\hline Viçe Nahiye merkezi-AbiSüfla Karyesi & $45+000$ & - & - & - & $5+000$ \\
\hline $\begin{array}{l}\text { Rize-Erzurum Vilayetine mülhak İspir } \\
\text { Kasabası hududu }\end{array}$ & $90+000$ & - & - & - & $16+000$ \\
\hline $\begin{array}{l}\text { Atina Kasabası merkezi_-Hemşin Nahiye } \\
\text { merkezi }\end{array}$ & $25+000$ & - & - & - & $5+000$ \\
\hline
\end{tabular}

Rize için ulaşım konusu büyük bir önem arz etmekteydi. Rize ilinin en önemli karayolu bağlantısı ise Karadeniz boyunca uzanan sahil yolu olarak karşımıza çıkmaktadır. Özellikle dağlık coğrafyası nedeniyle iç bölgelere ulaşımın sağlanması önemli bir sorun olarak devam ediyordu. Rize'nin güneyle bağlantısını sağlayan tek yol Rize-İspir yoluydu. ${ }^{109}$ Cumhuriyetin ilk yıllarından itibaren hükümet ve Rize belediyesi bu yolun yapımı için girişimlerde bulunmuşlardır. Bizzat Atatürk'ün “Bilhassa Rize-Erzurum şosesinin inşaası bu mıntıkayı dahi vasi faaliyet sahası ve refah temin edecektir. 341 bütçesinden bu yolun inşaası müsemmendir" sözleriyle yapılmasına verdiği önemi 17-18 Eylül 1924 tarihindeki Rize ziyaretinde görmekteyiz. ${ }^{110}$ Rize-İspir-Erzurum yolunun yapımı meselesi uzunca bir sure devam edecekti. 1928'den itibaren Rize-Kalkandere-İkizdere nahiyeleri üzerinden Vilayeti Erzurum'a bağlayacak yolun yapım çalışmalarına ağırlık verilmiştir. $\mathrm{Bu}$ yolun yapımına ancak 1930 yılında başlanacaktır. ${ }^{111}$ Rize'nin deniz ulaşımı ile ilgili devlet salnamelerinde özellikle Hopa başta olmak üzere iskelelerin ticari açıdan önemlerine değinilmiş ancak karayolları gibi ayrıntılı bilgilere yer verilmemiştir.

108 Türkiye Cumhuriyeti Devlet Salnamesi 1927-28, s.907.

109 "Rize", Yurt Ansiklopedisi, s.6391.

110 BCA, Fon:030.1.1, Yer: 40.237.17.

111 Yolun yapımı ile ilgili ayrıntılar için bkz. Işı1 Tuna, "Bayındırlık ve İmar Faaliyetleri”, Cumhuriyet Döneminde Rize I, RTEÜ Yayını, 2018, s.144-145.; Orhan Naci Ak, Rize Tarihi, Rize, 2000, s.217. 


\section{Sonuç}

Türkiye Cumhuriyeti devlet salnameleri içerdikleri idari, mülki, zirai ve sosyokültürel bilgiler bakımından ait oldukları dönemler ve vilayetler hakkında önemli veriler sunmaktadır. 1925-26, 1926-27, 1927-28 ve 1928-29 yıllarına ait devlet salnamelerinde Rize iline ait detaylı istatistiki verilere ulaşılmıştır. Bu salnamelerde öncelikle coğrafi ve tarihi bilgiler ardından mülki idare amir ve memurları (vali, defterdar, tahrirat müdürü, müftü, mahkeme reisi, müdde-i umumi, azalar, müstantık, sıhhiye, tapu, nüfus, baytar, muhasebe, posta-telgraf-telefon müdürler, belediye reisi) ile ilgili bilgiler verilmiştir. Salnamelerde halk sağlığıyla ilgili olan hastaneler ve salgın hastalıklara değinilmiş ayrıca merkez ve kazaların okul durumları da verilmiştir. Salnamelerde ayrıca toplumsal bir sorun olarak işlenen suçlara dair sayısal veriler sunulmuştur. Vilayetin yol durumu salnamelerde verilen diğer bilgilerdendir. Vilayette faaliyet gösteren cemiyetlere (Hilal-i Ahmer, Himaye-i Etfal, Teyyare, Cumhuriyet Halk Fırkası, Kayıkçılar, Muallimler Birliği gibi) ve ayrıca mevcut banka ve fabrikalara da yer verilmiş ve bu fabrikaların işletmecileri de tablolarla gösterilmiştir. Devlet salnameleri içerdikleri bu değerli bilgiler nedeniyle kent tarihi, sosyoiktisadi, halk kültürü, coğrafya, eğitim ve sağlık gibi alanlarda yapılacak çalışmalar için kaynak eserler durumundadır. 1925-1929 yıllarını kapsayan dört devlet salnamesinde Rize hakkında sunulan bilgiler analiz edildiğinde, ilin ekonomisinin tarıma, özellikle mısır tarımına dayalı olduğu görülür. 1927 yılından itibaren tarım ürünlerinin miktarlarında artış olmuştur. Günümüzde daha yoğun biçimde ilin iktisadi faaliyetlerinde lokomotif güç durumunda olan çayın henüz bahsedilen dönemde salnamelere yansımadığı görülmektedir. Bu çay tarımının henüz daha yeni yeni başlamış olmasından kaynaklanmaktadır. Başlangıçta mısıra dayanan tarım sektörünün giderek çay yönünde ağır basacağı izlenecektir. 1925-26 salnamesinde ilde fabrika veya şirket bulunmadığ 1 ifade edilirken 1927 y1lı salnamesinde ilde faaliyet gösteren fabrikalardan bahsedilmesi ilin sanayi bakımından gelişimindeki ivmeyi göstermesi açısından önemlidir. $\mathrm{Bu}$ tür gelişmelere ragmen özelikle ildeki feretiko adı verilen kendir bezleri üretiminin ve dokumacılığın ve hatta tütün üretiminin cumhuriyetin ilk yıllarında Rize'de son derece yaygın bir tarım-sanayi alanını teşkil ederken zaman içinde unutulmaya yüz tuttuklarını ve özellikle tütün üretiminin tamamen yok olduğunu görmekteyiz. Rize vilayetinin eğitim durumu analiz edildiğinde y1llar içinde okul sayılarının artmış olduğu, okula kayıtlı öğrenci sayılarında da benzer şekilde artışların olduğu gözlemlenmiştir. Devlet salnamelerinde verilen bilgiler arasında yer alan adli suç sayıları bakımından Rize vilayetinin suç oranlarının aynı nüfusa sahip diğer illere nazaran daha az olduğu ulaşılan bilgiler arasındadır. Vilayetin yol durumuna bakıldığında en önemli meselelerden biri olan ulaşım sorununun Cumhuriyetin ilk yıllarından bugünlere değin çözümü en zor olan konulardan biri olduğu anlaşılmaktadır. Karadeniz sahil yolunun ancak 2000'li yıllarda ve Rize-İspir-Erzurum yolunun henüz yeni tamamlanmış olduğu -ki halen inşaası devam eden bölümler bulunmaktadır- dikkate alındığında ilin ulaşım meselesinde uzun yıllar büyük zorluklar ve sıkıntılar çekmiş olduğu daha iyi idrak edilmektedir. 


\section{Kaynakça}

\section{Arşiv Belgeleri ve Resmi Yayınlar}

-BCA, Fon:030.18.1.1, Yer:1.4.5, 18 Haziran 1920.

-BCA, Fon:030.11.1.1, Yer:1.5.7, 26 Kasim 1923.

-BCA, Fon:030.1.1, Yer: 40.237.17.

-BOA, Șura-yı Devlet, 1830/27, 23 Aralık 1878.

- Sanayi Sayımı 1927, Devlet İstatistik Enstitüsü, Ankara, 1969.

- Türkiye Cumhuriyeti Devlet Salnamesi 1925-1926, Matbaa-i Amire, İstanbul,1926.

-Türkiye Cumhuriyeti Devlet Salnamesi 1926-1927, Matbuat Müdüriyet-i Umumiyesi, İstanbul, 1927.

-Türkiye Cumhuriyeti Devlet Salnamesi 1927-1928, Matbuat Müdüriyet-i Umumiyesi, İstanbul, 1928.

- Türkiye Cumhuriyeti Devlet Yıllı̆̆ 1928-1929, Devlet Matbaası, İstanbul, 1929.

- Türkiye Nüfusu, Başvekalet İstatistik Umum Müdürlüğü, Yayın No:3, Ankara, 1928.

Makale, Kitap, Ansiklopediler

-1967 Rize İl Yıllığı, Önder Matbaası, Ankara 1968.

- Ak, Orhan Naci, Rize Tarihi, Trabzon, Rize Halk Eğitim Merkezi Yayını, 2000.

- Ak, Orhan Naci, Rize'nin Yönetim Tarihi, Çınar Eğitim, Kültür ve Yardımlaşma Derneği Yayın1, Rize 2008.

-Aksoy, Volkan, “1933-50 Yılları Arasında Rize'nin İdari Teşkilatlanması”, Cumhuriyet Döneminde Rize I, RTEÜ Yayını, 2018,

-Alşan, Songül, "Rize'de Ziraat, Balıkçılık ve Hayvancılık (1923-50)", Karadeniz İncelemeleri Dergisi, Say1:27, 2019.

-Arer, Rahmi; Türkiyede Çaycılık ve Turistik Sosyal Kültürel Rize, İstanbul,1969.

-Arıkan, Mustafa, "Rize Adliyesi ve Arşivi", Cumhuriyet Döneminde Rize I, RTEÜ Yayını, 2018.

- Aydın, Bilgin, "Salname”, TDV İslam Ansiklopedisi, Cilt:36, 2009.

- Başaran, Sinan, "Cumhuriyet Dönemi Rize İdare Tarihi”, Türk İdare Dergisi, Sayı:486, Haziran 2018, Ankara, 2018.

- Başaran, Sinan, "Valiler”, Cumhuriyet Döneminde Rize I, RTEÜ Yayını, 2018.

- Başaran, Sinan, "Cumhuriyet Dönemi Rize Nüfusu", Fırat Üniversitesi Sosyal Bilimler Dergisi, Cilt:30, Say1:1, 2020.

-Cumhuriyetin 50. Yılında Rize, 1973 İl Yıllığı, Tisa Matbaası, Ankara, 1973.

-Çakmak, Fevzi, "Sağlık ve Sosyal yardımlaşma", Cumhuriyet Döneminde Rize I, RTEÜ Yayını, 2018.

- Çapa, Mesut, “Rize'nin Yakın Tarihine Bir Bakış”, Karadeniz İncelemeleri Dergisi, Sayı: 20, 2016.

- Çavuş, Ahmet, Rize İlinde Sanayii, Pegem Yayıncılık, Ankara, 2016.

- Çiçek, Rahmi, "Rize'nin İdari Yapısı”, Cumhuriyet Döneminde Rize I, RTEÜ Yay., Rize, 2018.

-Kopar, Metin, "Türkiye Cumhuriyeti Devlet Salnamelerinde Adiyaman (1925-1930)", Sosyal Bilimler Dergisi, Cilt:7, Sayı:13, 2017.

- Özdoğan, İsmail, Rize Sosyal, Siyasal ve Ekonomik Yapısı, Yayınlanmamış Yüksek 
Lisans Tezi, Muğla Üniversitesi SBE, Muğla, 2004.

-Özlü, Zeynel, "Cumhuriyetin İlk Yıllarında Bolvadin Kazasına Dair Bulgular", Bolvadin Araştırmaları, Eğitim Yayınevi, Konya, 2018.

- Polat, Pınar, "Rize'nin Coğrafi Durumu”, Cumhuriyet Döneminde Rize I, RTEÜ Yay., Rize, 2018.

- Polat, Pınar-Murat Sunkar, “Rize'nin İklim Özellikleri ve Rize Çevresinde Uzun Dönem Sıcaklık ve Yağış Verilerinin Trend Analizleri”, Fırat Üniversitesi Sosyal Bilimler Dergisi, Cilt: 27, Sayı:1, 2017.

-"Rize", Yurt Ansiklopedisi, C.9, Anadolu Yayınc1lık, İstanbul 1982-1983.

-Şahin, Güneş, "1926-27 ve 1928 Türkiye Cumhuriyeti Devlet Salnamelerinde Van Vilayeti”, Turkish Studies, Volume:10/9, 2015.

- Taşpınar, Ali, Rize Tarihi, Rize Ticaret Borsası Yayını, Rize 2004.

- Taymas, Abdullah Battal, Yeşil Rize ve İli, Doğuş Matbaası, Ankara 1950.

- Tekir, Hürü Sağlam, “1927-1928 Devlet Salnamesinde Sinop Vilayeti”, Kafkas Üniversitesi Sosyal Bilimler Enstitüsü Dergisi, Sayı:13, 2014.

- Topaloğlu, İhsan, Bölge Tarihinde Rize, Topaloğulları Kültür Dayanışma Derneği Yayını, Trabzon, 1998.

-Tuna, Işı1, "Bayındırlık ve İmar Faaliyetleri”, Cumhuriyet Döneminde Rize I, RTEÜ Yayını, 2018.

-Yıldırım, Özlem, "Cumhuriyet Döneminde Rize'de Tarım, Hayvancılık ve Ticaret", Cumhuriyet Döneminde Rize I, RTEÜ Yayını, 2018.

-Yılmaz, Hadiye, "Türkiye Cumhuriyeti Devlet Salnamesi 1925-26'da Giresun Vilayeti”, Karadeniz Sosyal Bilimler Dergisi, Cilt:8, Say1:15, 2016.

-Yılmaz, Hadiye, "Türkiye Cumhuriyeti Devlet Salnamelerinde Ordu Vilayeti”, Karadeniz, Say1:31, 2016.

-Yormaz, Elif, Rize Gazetesine Göre Rize'de Sosyo-Ekobomik ve Kültürel Hayat, Yayınlanmamış Yüksek Lisans Tezi, KTÜ SBE, Trabzon, 2016. 


\section{Ekler}

\section{Ek 1:1927-28-Rize Vilayetindeki Fabrikaların Üretim Miktarları (Türkiye Cumhuriyeti Devlet Salnamesi 1927-28, s.906.)}

\begin{tabular}{|l|l|l|l|l|l|}
\hline \multicolumn{5}{|c|}{ Fabrika, Değirmen } \\
\hline Sahiplerinin Adı & Tabiiyetleri & $\begin{array}{l}\text { T e s i s } \\
\text { Tarihleri }\end{array}$ & $\begin{array}{l}\text { M a k in e } \\
\text { Türü }\end{array}$ & $\begin{array}{l}\text { Beygir } \\
\text { Gücü }\end{array}$ & $\begin{array}{l}\text { Bir } \\
\text { Miktar1-Kilo }\end{array}$ \\
\hline Sadıkzade Ruşen Bey & Türk & 927 & $\begin{array}{l}\text { B u h a r } \\
\text { Makinesi }\end{array}$ & $\begin{array}{l}225 \\
15.000 \text { metreküp gayrı } \\
\text { mamul pamuk }\end{array}$ \\
\hline $\begin{array}{l}\text { Sabuncuzade İbrahim ve } \\
\text { Mahdumu Hüseyin Efendi }\end{array}$ & $/ /$ & 1338 & $/ /$ & - & Adet -Kilo \\
\hline $\begin{array}{l}\text { Şeyh Hüseyinzade Murad } \\
\text { Efendi }\end{array}$ & $/ /$ & 1339 & $/ /$ & - & $6.000-3.000$ \\
\hline $\begin{array}{l}\text { Şeyh Hüseyinzade Hüseyin } \\
\text { Efendi }\end{array}$ & $/ /$ & 1332 & $/ /$ & - & $2.000-1.000$ \\
\hline Kürkçüzade Hamid Efendi & $/ /$ & 1332 & $/ /$ & - & $6.000-3.000$ \\
\hline $\begin{array}{l}\text { Sabuncuzade } \\
\text { Ahmet Efendi }\end{array}$ & $/ /$ & 1335 & $/ /$ & - & $5.000-2.500$ \\
\hline Dalzade Biraderler & $/ /$ & 1332 & $/ /$ & - & $6.000-3.000$ \\
\hline Velizade Ahmet Efendi & $/ /$ & 1332 & $/ /$ & - & $5.000-2.500$ \\
\hline Bıyıkoğlu Süleyman Efendi & $/ /$ & 1335 & $/ /$ & - & $4.000-2.000$ \\
\hline Balzade Emrullah Efendi & $/ /$ & 1338 & $/ /$ & - & $6.000-3.000$ \\
\hline $\begin{array}{l}\text { Şeyh Hüseyinzade Tahsin } \\
\text { Efendi }\end{array}$ & $/ /$ & 1332 & $/ /$ & - & $7.000-3.500$ \\
\hline Füsufzade Ali Rıza Efendi & $/ /$ & 1338 & $/ /$ & - & $7.000-3.500$ \\
\hline Kotikoğlu Halim Efendi & $/ /$ & 1332 & $/ /$ & - & $4.000-2.000$ \\
\hline Ahmet oğlu Mustafa Efendi & $/ /$ & 1340 & $/ /$ & - & $4.000-2.000$ \\
\hline $\begin{array}{l}\text { Uzunömer oğlu Ahmet } \\
\text { Efendi }\end{array}$ & $/ /$ & 1340 & $/ /$ & - & $3.000-1.500$ \\
\hline Menlazade Said Efendi & $/ /$ & 1340 & $/ /$ & - & $1.000-500$ \\
\hline Ayvazzade Salih Efendi & $/ /$ & 1341 & $/ /$ & - & 100 Top 100 \\
\hline Kanburoğlu Ahmet Efendi & $/ /$ & 1340 & $/ /$ & - & $100 / / 100$ \\
\hline Eyüpzade Mahmut Efendi & $/ /$ & 1339 & $/ /$ & - & $500 / / 500$ \\
\hline & & & & \\
\hline
\end{tabular}


Ek 2:1925-26-Rize Vilayeti Kazalarındaki Mülki İdare Amir ve Memurları-(Türkiye Cumhuriyeti Devlet Salnamesi 1925-26, s.632.)

Atina Kazası

\begin{tabular}{|l|l|}
\hline Atina-Memuriyet & İsim \\
\hline Kaymakam & İbrahim Edhem Bey \\
\hline Mal Müdürü & Bekir Sttk Bey \\
\hline Mfü̈ftü & Ömer Lütfi Efendi \\
\hline Mahkemei Asliye reisi & Nizameddin Bey \\
\hline Mahkemei Asliye Mğddei Umumisi & Mehmed Bey \\
\hline Mahkemei Asliye Azast & Faik Bey \\
\hline Mahkemei Asliye Azast & - \\
\hline Hakim & Halil Bey \\
\hline Mustantı & Halid Yaşar Bey \\
\hline$\ldots$. (Heşhir)Nahiyesi Sulh Hakimi & Arif Bey \\
\hline
\end{tabular}

Hopa Kazasl

\begin{tabular}{|l|l|}
\hline Kaymakam & Sabri Bey \\
\hline Mal Müdürü & Hüseyin Bey \\
\hline Müftï & Rlza Efendi \\
\hline Hakim & Ali Bey \\
\hline Müddei Umumi & Semseddin Bey \\
\hline Mustanttk & Ahmed Astm Bey \\
\hline
\end{tabular}

Ek 3:1926-27-Rize Vilayeti Kazalarındaki Mülki İdare Amir ve Memurları-(Türkiye Cumhuriyeti Devlet Salnamesi 1926-27, s.884.)

Atina Kazası

\begin{tabular}{|l|l|}
\hline Memuriyet & İsim \\
\hline Kaymakam & İbrahim Ethem Bey \\
\hline Mal Müdürü & - \\
\hline Mahkemei Asliye Reisi & Mustafa Nizameddin Bey \\
\hline Müddei Umumi & Mehmet Bey \\
\hline Mahkeme Azasl & Hüseyin Avni Bey \\
\hline Mahkeme Azasl & Mesut Bey \\
\hline Mustantı & Halit Yaşar Bey \\
\hline Posta ve Telgraf Müdürü & Rüstü Bey \\
\hline
\end{tabular}


Hopa Kazası

\begin{tabular}{|l|l|}
\hline Memuriyet & İsim \\
\hline Kaymakam & Agah Bey \\
\hline Mal Müdürü & Hamdi Bey \\
\hline Mahkemei Asliye Reisi & Ali Necmeddin Bey \\
\hline Müddei Umumi & Şemseddin Bey \\
\hline Mustantı & Astm Bey \\
\hline Arhavi Sulh Hakimi & Hüsnü Bey \\
\hline Posta ve Telgraf Müdürü & Necip Bey \\
\hline
\end{tabular}

Ek 4:1927-28-Rize Vilayeti Kazalarındaki Mülki İdare Amir ve Memurları-(Türkiye Cumhuriyeti Devlet Salnamesi 1927-28, s.910.)

Atina Kazası

\begin{tabular}{|l|l|}
\hline Memuriyet & Ísim \\
\hline Kaymakam & İbrahim Ethem Bey \\
\hline Mal Müdürü & Bekir Bey \\
\hline Müftü & Ömer Lütfi Efendi \\
\hline Müddei Umumi & Naci Bey \\
\hline Hukuk Hakimi & Bilal Bey \\
\hline Ceza Hakimi & Kamil Bey \\
\hline Müstentik & Halid Bey \\
\hline Hükümet Tabibi & Mustafa Fahri Bey \\
\hline Posta ve Telgraf Müdürü & Rüşü̈Bey \\
\hline
\end{tabular}

Hopa Kazasl

\begin{tabular}{|l|l|}
\hline Memuriyet & İsim \\
\hline Kaymakam & Agah Bey \\
\hline Mal Müdürü & Hamdi Bey \\
\hline Müftü & Mehmet Ziya Efendi \\
\hline Müddei Umumi & Şemseddin Bey \\
\hline Hakim & Necmeddin Abbas Bey \\
\hline Müstentik & Astm Bey \\
\hline Hükümet Tabibi & Hüseyin Hüsnü Bey \\
\hline Posta ve Telgraf Müdürü & Necip Bey \\
\hline
\end{tabular}


Ek 5:1928-29-Rize Vilayeti Kazalarındaki Mülki İdare Amir ve Memurlar1-(Türkiye Cumhuriyeti Devlet Salnamesi 1928-29, s.516.)

\begin{tabular}{|l|l|}
\multicolumn{2}{l}{ Atina Kazast } \\
\hline Memuriyet & İsim \\
\hline Kaymakam & A.Feridun Bey \\
\hline Mal Müdürü & Hamdi Bey \\
\hline Müftü & Ömer Lütfi Efendi \\
\hline Hukuk Hakimi & Hasan Bahri Bey \\
\hline Ceza & Kamil Bey \\
\hline Müstentik & Halit Bey \\
\hline Hükümet Tabibi & M.Fahri Bey \\
\hline Posta ve Telgraf Müdürü̈ & Rüstü Bey \\
\hline
\end{tabular}

Hopa Kazası

\begin{tabular}{|l|l|}
\hline Memuriyet & Ísim \\
\hline Kaymakam & Agah Bey \\
\hline Mal Müdürü & Bekir Bey \\
\hline Müftü & M.Ziya Efendi \\
\hline Hakim & N.Abbas Bey \\
\hline Müddei Umumi & Şükrü Bey \\
\hline Müstentik & Astm Bey \\
\hline Hükümet Tabibi & H.Hüsnü Bey \\
\hline Posta ve Telgraf Müdürü & Necip Bey \\
\hline
\end{tabular}

Ek 6:1928-29-Rize Vilayetinde Yollar (Türkiye Cumhuriyeti Devlet Yıllığ 1928-29, s.513.)

\begin{tabular}{|c|c|c|c|c|c|}
\hline \multirow{3}{*}{ Yolun Başı-Sonu } & \multirow{2}{*}{$\begin{array}{c}\text { Yolun } \\
\text { Uzunluğu }\end{array}$} & \multicolumn{4}{|c|}{ Şoseler } \\
\hline & & $\begin{array}{c}\text { Sağlam } \\
\text { Klsmı }\end{array}$ & $\begin{array}{c}\text { Tamir } \\
\text { Olunmakta }\end{array}$ & $\begin{array}{c}\text { Tamir } \\
\text { Başlanmamış }\end{array}$ & $\begin{array}{l}\text { Yeni İnşa } \\
\text { Olunmakta }\end{array}$ \\
\hline & $\mathrm{Km}$ & Km & $\mathrm{Km}$ & $\mathrm{Km}$ & $\mathrm{Km}$ \\
\hline Rize-Of Hududu & $178+000$ & $75+000$ & $75+000$ & $103+000$ & $0+000$ \\
\hline Atina - Hemşin & $25+000$ & $0+000$ & $0+000$ & $0+000$ & $5+000$ \\
\hline Hopa-Artvin Borçka Hududu & $12+750$ & $0+000$ & $0+000$ & $0+000$ & $12+750$ \\
\hline Rize-Erzurum İspir Hududu & $125+000$ & $0+000$ & $0+000$ & $0+000$ & $16+000$ \\
\hline Viçe Nahiyesi-Abısüfla Köyü & $54+000$ & $0+000$ & $0+000$ & $0+000$ & $0+000$ \\
\hline $\begin{array}{l}\text { Arhoy Nahiye merkezinden-Potur } \\
\text { (Potohor) köyü Yusufeli hududu }\end{array}$ & $25+000$ & $0+000$ & $0+000$ & $0+000$ & $10+000$ \\
\hline
\end{tabular}


Ek 7: 1927-28-Rize Milletvekilleri (Türkiye Cumhuriyeti Devlet Salnamesi 1927-28, s.900)

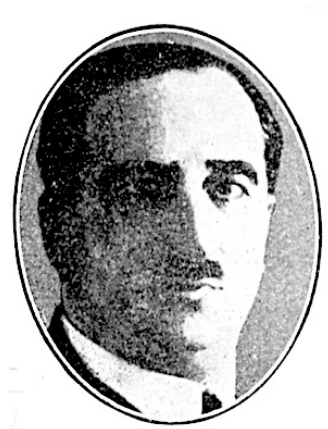

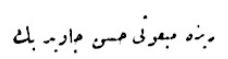

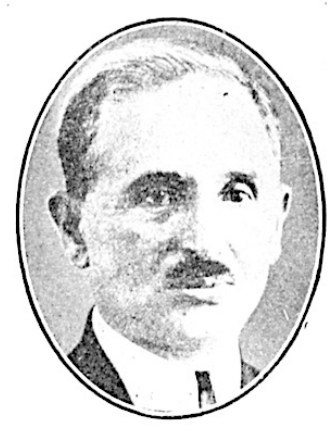

(ب)

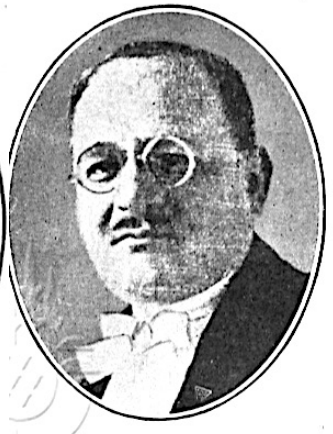

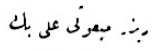

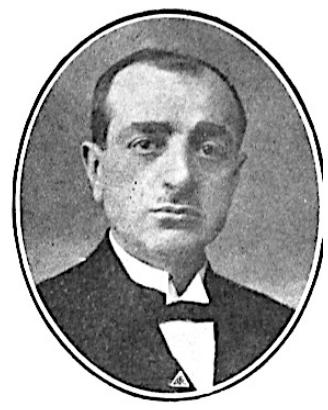

UC:
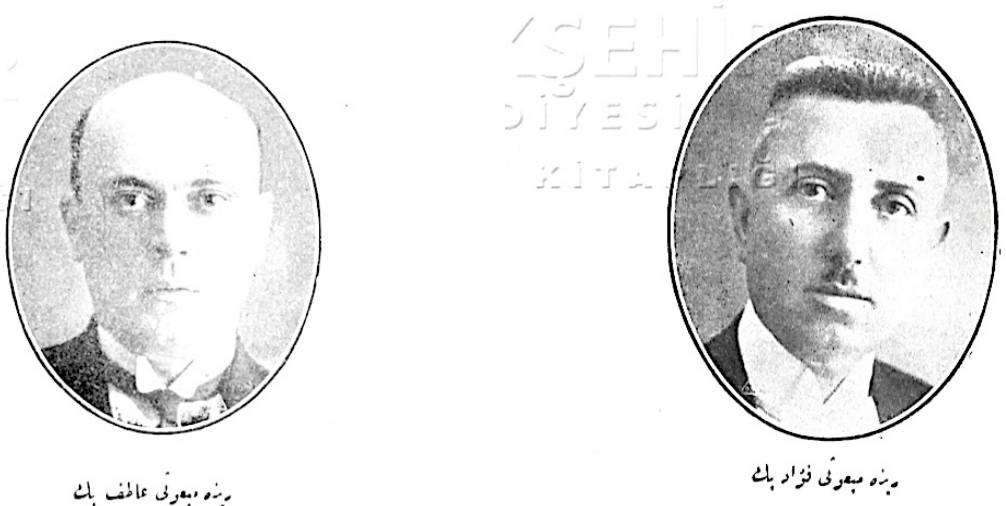

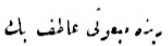

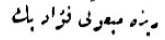


Ek 8: 1925-26-Rize Vilayeti Memurları Rize Vilayeti Kazalarındaki Mülki İdare Amir ve Memurları-(Türkiye Cumhuriyeti Devlet Salnamesi 1925-26)

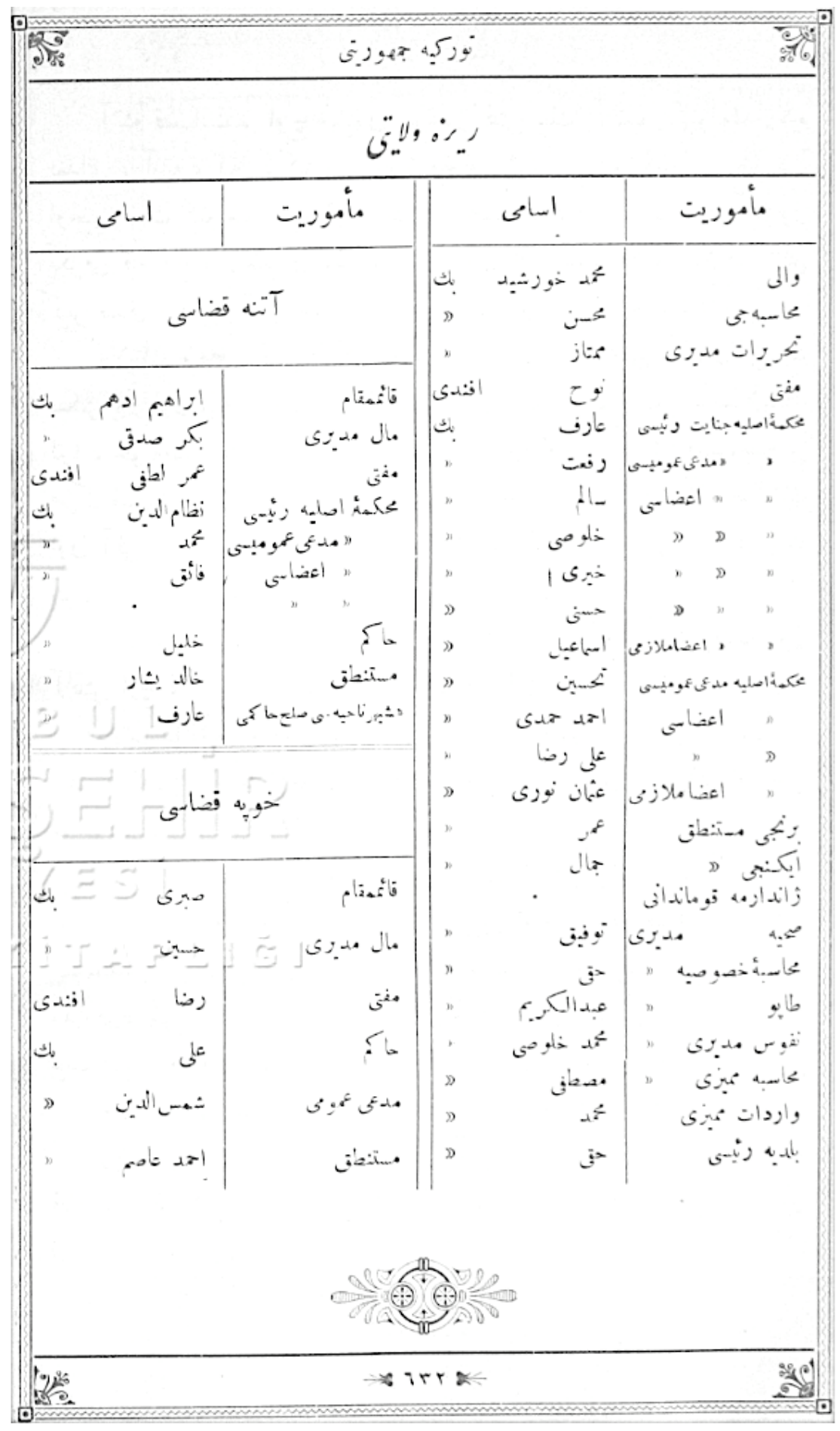


Ek 9:Rize Vilayeti Haritas1-1925-26 (Türkiye Cumhuriyeti Devlet Salnamesi 1925-26, s.633)

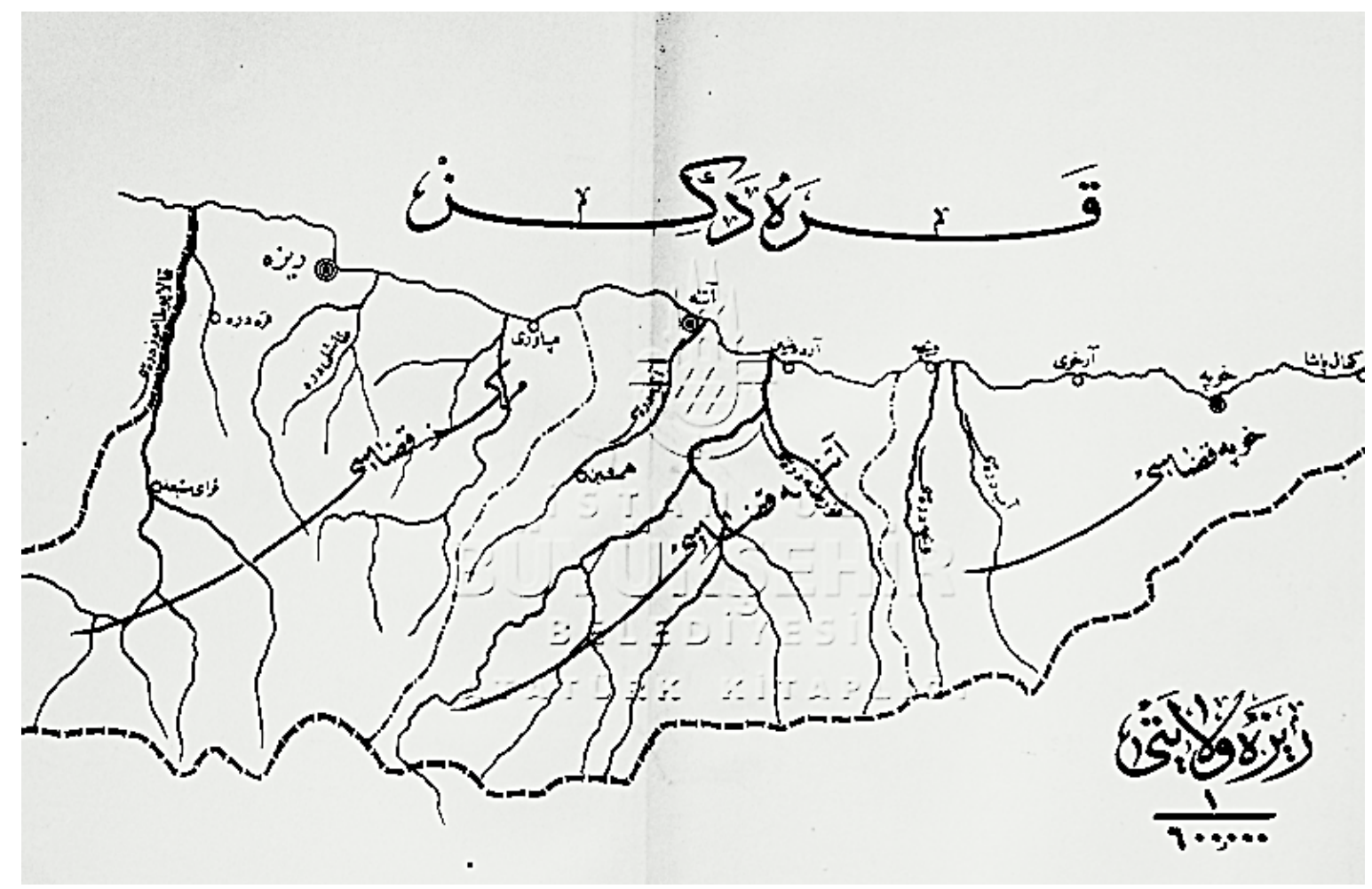

